2008s-12

\title{
Stock Exchange Markets for New Ventures
}

Cécile Carpentier, Jean-François L'Her, Jean-Marc Suret

\begin{tabular}{c}
\hline Série Scientifique \\
Scientific Series
\end{tabular}

Montréal

Avril 2008

(C) 2008 Cécile Carpentier, Jean-François L’Her, Jean-Marc Suret. Tous droits réservés. All rights reserved. Reproduction partielle permise avec citation du document source, incluant la notice (C).

Short sections may be quoted without explicit permission, if full credit, including (C) notice, is given to the source.

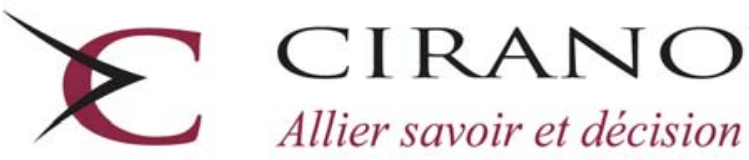

Centre interuniversitaire de recherche en analyse des organisations 


\section{CIRANO}

Le CIRANO est un organisme sans but lucratif constitué en vertu de la Loi des compagnies du Québec. Le financement de son infrastructure et de ses activités de recherche provient des cotisations de ses organisations-membres, d'une subvention d’infrastructure du Ministère du Développement économique et régional et de la Recherche, de même que des subventions et mandats obtenus par ses équipes de recherche.

CIRANO is a private non-profit organization incorporated under the Québec Companies Act. Its infrastructure and research activities are funded through fees paid by member organizations, an infrastructure grant from the Ministère du Développement économique et régional et de la Recherche, and grants and research mandates obtained by its research teams.

\section{Les partenaires du CIRANO}

\section{Partenaire majeur}

Ministère du Développement économique, de l’Innovation et de l’Exportation

\section{Partenaires corporatifs}

Alcan inc.

Banque de développement du Canada

Banque du Canada

Banque Laurentienne du Canada

Banque Nationale du Canada

Banque Royale du Canada

Banque Scotia

Bell Canada

BMO Groupe financier

Bourse de Montréal

Caisse de dépôt et placement du Québec

DMR Conseil

Fédération des caisses Desjardins du Québec

Gaz de France

Gaz Métro

Hydro-Québec

Industrie Canada

Investissements PSP

Ministère des Finances du Québec

Raymond Chabot Grant Thornton

State Street Global Advisors

Transat A.T.

Ville de Montréal

\section{Partenaires universitaires}

École Polytechnique de Montréal

HEC Montréal

McGill University

Université Concordia

Université de Montréal

Université de Sherbrooke

Université du Québec

Université du Québec à Montréal

Université Laval

Le CIRANO collabore avec de nombreux centres et chaires de recherche universitaires dont on peut consulter la liste sur son site web.

Les cahiers de la série scientifique (CS) visent à rendre accessibles des résultats de recherche effectuée au CIRANO afin de susciter échanges et commentaires. Ces cahiers sont écrits dans le style des publications scientifiques. Les idées et les opinions émises sont sous l'unique responsabilité des auteurs et ne représentent pas nécessairement les positions du CIRANO ou de ses partenaires.

This paper presents research carried out at CIRANO and aims at encouraging discussion and comment. The observations and viewpoints expressed are the sole responsibility of the authors. They do not necessarily represent positions of CIRANO or its partners. 


\title{
Stock Exchange Markets for New Ventures*
}

\author{
Cécile Carpentier ${ }^{\dagger}$, Jean-François L'Her ${ }^{\ddagger}$, Jean-Marc Suret ${ }^{\S}$
}

\begin{abstract}
Résumé / Abstract
Au Canada, un marché boursier de capital de risque inscrit des entreprises à très faible capitalisation, avant même qu'elles ne rapportent des revenus. Ce marché est en concurrence directe avec le capital de risque institutionnel et informel. Le taux de rendement de ce marché boursier est supérieur à celui du capital de risque, et ce marché amène sept fois plus d'entreprises au marché principal, par " graduation », que ne le fait le capital de risque à la suite d'émissions initiales. Nous n'observons aucune performance anormale négative à la suite des graduations. Nos résultats indiquent que le capital de risque canadien ne semble pas disposer des avantages que la théorie attribue généralement à ce type d’investisseurs en matière de sélection des projets, de supervision ou encore de capacité de disposition des placements.
\end{abstract}

Mots clés : capital de risque, démarrage, graduation, marché boursier

In Canada, a venture stock market lists micro-capitalization firms that are at a pre-revenue stage, and competes with both formal and informal venture capital (VC). This market provides a higher rate of return and is able to provide seven times more new listings to the main exchange than the VC market. We do not evidence post-graduation underperformance, and indeed, new listings on a main exchange can succeed even if they originate from a public venture market. Our results do not support the theoretical arguments that confer specific advantages on the VCs with regard to screening, monitoring and exiting new ventures.

Keywords: Public venture capital, start-up, graduation, success rate, stock exchange

\footnotetext{
* The authors assume full responsibility for any errors remaining in the text. The views expressed in this article are those of the authors, and do not necessarily reflect the position of the Caisse de dépôt et placement du Québec.

${ }^{\dagger}$ Cécile Carpentier is from Laval University, email: Cecile.carpentier@fsa.ulaval.ca.

‡ Jean-François L’Her is from La Caisse de dépôt et placement du Québec, e-mail: jlher@lacaisse.com.

$\S$ Jean-Marc Suret (corresponding author) is from Laval University, Faculty of Administrative Science, School of Accountancy, 6226 Pavillon Palasis-Prince, G1K 7P4, Quebec, Canada, Phone: (418) 6567134,

Fax: (418) 656 7746, email: Jean-marc.suret@fsa.ulaval.ca.
} 


\section{EXECUTIVE SUMMARY}

Emerging companies usually obtain outside equity financing from specialized investors, through formal and informal venture capital (VC) networks. These investors have developed skills, methods and tools to select, fund and monitor the most promising ventures. For these ventures, the growth path leads to the initial public offering (IPO) and exchange listing, which is the ultimate mark of success for venture capitalists (VCs). The company must then fulfill the minimal listing requirements, including having a track record of positive earnings and sufficient capitalization and float. In Europe, the emergence of technological companies and the willingness to foster a vibrant VC industry have prompted several countries to implement junior (or new) stock markets, which have had varying, but generally negative, outcomes. These junior markets apply more lenient listing rules. VCs view these markets as exit vehicles.

In Canada, a public venture capital market, the TSX Venture Exchange (TSXV), acts as a direct competitor to both formal and informal VC markets. ${ }^{1}$ Newly created companies with no history or sales are allowed to list on the TSXV because of its very minimal listing requirements. The ultimate goal of the TSXV is to graduate its best performers to the main exchange, the Toronto Stock Exchange (TSX), which according to international standards, is itself a junior market, and is partly fed by public venture capital. The literature generally considers that neither stock exchanges nor individual investors have the tools, skills and knowledge needed to successfully finance emerging companies. Indeed, even though they select companies at a more advanced developmental stage than does the TSXV, several junior markets devoted to growing companies have been deemed failures. Accordingly, both the literature and the past experiences of new markets indicate that the Canadian strategy is highly risky, and that the returns of such a market should be lower than those of a private VC market. Moreover, because of the lack of the asserted value-added activities of VCs and their role in backing IPOs, both the development and the exit rate of new ventures listed on the public venture exchange should be much lower than in the private market.

By analyzing new listings on the TSXV over a 21-year period, we evidence that the lax initial listing requirements and the stimulus provided by backdoor listings open up this venture exchange to a wide variety of companies. 3,857 companies were listed on the TSXV from 1986 to 2006,

\footnotetext{
${ }^{1}$ For an illustration, see the figure entitled: "Where TSX Venture Fits" on page 4 of the TSXV Guide to Public Venture Capital, at http://www.tsx.com/en/pdf/GoingPublicOnTSXVenture.pdf
} 
which is equal to $60 \%$ of the number of IPOs reported in the U.S. during the same period. The entrants are characterized by the following three figures: $49.26 \%$ report no revenues, the pre-listing median shareholders' equity is CAN\$260,000, and the median gross proceeds are CAN\$650,000. These new listings are new business ventures, which are in fact penny stock IPOs. Their reported sales and assets are considerably lower than those of any junior market, including the London Alternative Investment Market (AIM). Canadian companies list on a market at a stage where there is minimal VC interest in them. In that respect, the TSXV competes with business angels when it comes to financing new ventures. On average, the rate of return of the TSXV estimated using all these new listings is higher than that of the main market.

Like the TSXV, we consider a company to be successful if it graduates to the main market. We document graduations and measure the success rate for new listings. We also estimate the time to success, which goes from the listing time to the graduation date, and compare these data with those reported for the VCs' original investments and for VC-backed IPOs. We find that the success rate of the TSXV is four times the estimated rate for traditional VCs. However, the time to success is longer for the public venture market than for the conventional private $\mathrm{VC}$ market. We note seven new listings on the TSX resulting from graduations of TSXV companies for each VC-backed IPO. Thus, the Canadian experience of opening the door of a venture exchange to early-stage companies produces positive results.

Graduations seem to represent true successes. We note a strong rally before graduation and normal returns thereafter except during the High-Tech bubble period. On average, graduate companies exhibit strong performance before their migration, and provide a steady return to investors on the main market. The run-up could explain why the public venture market outperforms the private $\mathrm{VC}$ market. Even though they may grow without support from knowledgeable investors, and may lack the backing of specialized investors when listing on the main market, graduate companies provide reasonable rates of return. Some graduates, firms concentrated in the High-Tech and Minerals sectors, perform poorly, and we attempt to explain why. Further, because some of these firms do not report revenues, their real value is more difficult to appraise.

Our results have the following implications. Firstly, developing new companies through a public venture stock market can have positive outcomes: firms with no access to VC financing are brought into the fold, and a greater number of firms are able to graduate than is the case with VC-backed 
IPOs. Secondly, after maturing in the context of a public venture exchange, graduating firms produce adequate returns on average, except for those reporting no revenues. Lastly, an investor seeking exposure to $\mathrm{VC}$ would have been better off investing in the public rather than in the conventional market. Simple screening rules applied at the initial listing time would have allowed such an investor to earn an average annual return of $24.45 \%$; interestingly, during the 1995-2005 subperiod, the private VC industry posts a meager $-3 \%$. In Canada, our results are not consistent with the classical premise that private VCs have superior skills, tools and value-added capabilities.

\section{INTRODUCTION}

According to Cassar (2004), how business start-ups are financed is one of the most fundamental questions of enterprise research. Conventional equity financing of new ventures is generally provided by specialized investors through informal and formal VC networks. ${ }^{2}$ Furthermore, these investors are assumed to provide several valuable services to emerging businesses. The limits of this financing model are well known. Firstly, such specialists demand high costs of capital and finance only a few of very many proposals received. Secondly, they focus on the few sectors in which a high rate of return can be expected. Thirdly, structuring a VC market is not an easy task, and, in most countries except in the U.S., and partially in the U.K., VC is generally perceived as insufficient or badly structured. To fill the assumed equity gap for emerging businesses, countries have implemented a large set of public programs. They have also attempted to fill this gap with specialized stock markets or specific segments of the main markets.

Junior (or new) markets have been established to ease the development of emerging businesses in Europe (Bottazzi and Da Rin, 2005), Japan (Mizuno, 2006), the U.K. (Jenkinson and Ramadorai, 2007), and several Asia-Pacific countries. Several papers have analyzed the global performance of these exchanges, mainly following the collapse of the first and second waves of the new markets in Europe (Rasch, 1994; Goergen et al., 2003), but also after the fall of the Amex emerging companies marketplace (Aggarwal and Angel, 1999) and of the predecessor of the AIM - the Unlisted Securities Market (Buckland and Davis, 1989). In spite of these failures, the development of small and medium sized enterprise (SME) markets devoted to high growth companies is still promoted by VC associations (EVCA, 2004), mainly because such markets are generally deemed to constitute a

\footnotetext{
${ }^{2}$ VCs are not the only investors involved in the early stages of financing: business angels and family members constitute the informal VC market. We consider all these forms of financing as VC, but we rely on formal VC statistics for comparisons, as they are the only available data.
} 
channel to facilitate the exit of VCs (Giudici and Roosenboom, 2004). Conversely, there is sparse evidence of the positive outcome of such markets. As mentioned by Korcsmaros (2002, p.4), "the jury is still out on the accomplishments attained by stock exchanges dedicated to serving SMEs and the extent to which they have been successful in bringing SMEs to the capital market". While there is support for the notion that, especially for emerging economies, stock exchanges are particularly relevant to helping medium-sized indigenous firms gain access to finance and promoting local market development, there are specific doubts as to the suitability of SMEs for capital markets owing to the asymmetry and agency problems inherent to this category of firms. Bottazzi and $\mathrm{Da}$ Rin (2002) provide partial evidence of the success of junior markets in developing new companies. From 1996 to 2001, 545 companies floated an IPO on one of the new markets in Europe. Ninetyfive of those firms subsequently graduated to a more senior market, and are considered to be "born post new markets" (Bottazzi and Da Rin, 2002, p. 35). These authors (2005) propose the role of markets targeted at entrepreneurial ventures as one of the research themes awaiting further investigation.

In Canada, the use of the public market to finance emerging companies has been severely overstretched. Here, the main market - the TSX - is considered as a junior market, and is fed mainly by a public venture market, the TSXV. This venture market lists companies having no history, no revenues and with minimal assets. Most of the companies entering the TSXV are start-ups, and backdoor listings are nearly as frequent as IPOs, allowing for the listing of companies that do not fulfill the initial listing requirements. ${ }^{3}$ When a company graduates to the more senior market, the TSXV considers it a success, and provides extensive help and services to ease this migration; this is not unlike how VCs consider the IPOs of the companies they back as a success. This situation offers a unique opportunity to analyze whether such a public venture market can have a success rate similar to that of a traditional $\mathrm{VC}$ market, and if it can develop profitable ventures.

Our general objective is to validate the widely accepted assessment that because VCs have developed specific skills and tools to deal with the asymmetry of information and agency problems specific to new ventures, individual investors cannot compete with them. Accordingly, we analyze

\footnotetext{
${ }^{3}$ In 2005, the amendments to the TSX Policy 5.2 put Reverse Take-overs on an equal footing with IPOs to the degree that they are both "new listing" transactions. Ever since these changes came into effect, the Exchange applies the same eligibility, minimum listing, escrow, halt and sponsorship standards to issuers undertaking either transaction.
} 
the following dimensions: firstly, we measure the global performance of the public venture market and compare this performance with that of the VC market; secondly, we study the efficiency of the venture stock market in feeding the TSX through graduations, and we compare the success rates and times from listing to graduation with the corresponding rates and times observed for VC-backed IPOs; thirdly, we determine whether these graduations are indeed successes, based on the long-run performance of the population of TSXV firms that graduate to the TSX - this part of the study supplements the scant evidence in place relative to the firms that list on a more senior market; fourth, we attempt to determine whether the long-run performance can be explained by the characteristics of the graduating companies, and lastly, we examine how the public venture model can be improved. To the best of our knowledge, our paper is the first to provide an extensive analysis of the TSXV. ${ }^{4}$

The paper is structured as follows. In the first section, we describe the Canadian institutional context. In the second section, we summarize the literature and develop our hypotheses. We present data and stylized facts relative to new listings and graduations in the third section. Section four describes global performance, graduate companies' characteristics, success (graduation) rates and times from listing to graduation. Section five analyzes the average long-run performance of the graduates, and the cross-sectional variation in performance. Section six is devoted to the prediction of graduation and of possible improvements that can be made to the TSXV model, while section seven concludes.

\section{INSTITUTIONAL CONTEXT}

\section{A. Global Considerations}

According to Schulman (1999), "a small and medium size business market, sometimes known as a parallel or junior market, provides an exchange facility where the listed securities of small and midsize companies can be traded efficiently and competitively (...). It provides a nursing ground for

\footnotetext{
${ }^{4}$ Firms can list in this market through IPOs or the capital pool company (CPC) program. A few previous empirical analyses use subsamples of one of these categories of issues, without providing a global analysis of the TSXV performance. Kooli and Suret (2004) analyze the long-run performance of 445 Canadian IPOs between 1991 and 1998, including those launched on the TSXV; the same authors (2003) study the issuing costs of these issues. Carpentier and Suret (2006) provide an analysis of the CPCs from 1995 to 2001. Kooli (2006) analyzes the underpricing of newly listed companies, including the TSXV and CPC IPOs, from 1991 to 1998. Nicholls (2006) and Carpentier et al. (2003) provide general descriptions of the Canadian markets and Canadian IPOs, including TSXV firms, respectively.
} 
small companies to expand until they are large enough for the main market - this will increase new listings for the main market". A recent survey by the World Federation of Exchanges (WFE) ${ }^{5}$ lists 28 SME exchanges in the world. SME markets state minimal listing rules at low levels, which allow SMEs to float IPOs. However, the rules usually include minimal profitability and size requirements (Schulman, p. 22). According to Bottazzi and Da Rin (2002), in the Euro.nm, pre-IPO equity must be higher than Euro1.5 million and IPO proceeds must be over Euro5 million (CAN\$8 million). ${ }^{6}$ Schulman (1999) reports that several SME markets have some variants on a minimal profitability requirement for listing, expressed as: "Satisfactory operating profits over the last three years" Parallel Market (Athens); Cumulative net profit over the last 3 years - MMEX (Mexico); Profit earning capacity - OTC-List (Stockholm); Profitable in one of the last 3 years - SMB-list (Oslo); 3 to 5 years of average profitability - Second Board (Kuala Lumpur); Precise profitability minimums - SESDAQ (Singapore)." Such rules generally prevent the listing of firms at a pre-revenue stage, and indicate that most SME markets require profitability.

Using the statistics provided by the WFE, we can estimate the average capitalization of the firms listed on these SME markets, at the end of 2006. For the largest markets, the mean capitalization in USD million ranges from 39.24 (Bombay Indonext), 80.62 (Kosdaq), 108.61 (AIM) to 128.69 (SESDQ, Singapore). SME markets generally list companies with larger sizes than does the TSXV, where the mean (median) capitalization, in December 2006 was CAN\$21.02 (9.08) million.

A few markets do not impose any minimal listing requirement. The AIM in London for instance, only requires that every company seeking admission appoint a Nominated Advisor, or Nomad, and a broker. The Nomad must ensure that "the admission and conduct of a company do not impact adversely on the reputation and integrity of the exchange" (Rousseau, 2006, p. 97). Thus, the advisor helps determine what the market will sustain. Derrien and Kecskes (2007) measure mean (median) proceeds equivalent to CAN\$15 million (CAN\$6.84 million); the median operating income of AIM issuers is negative, but the market capitalization and revenues are CAN\$31.57 million and CAN\$3.32 million, respectively. This market cannot be considered a public venture

\footnotetext{
${ }^{5}$ See World Federation of Exchanges, Annual Report and Statistics 2006, section 5, entitled Small and Medium Enterprises Markets online on the WFE website (last visited March 19, 2008).

${ }^{6}$ Euro.nm was created in spring 1997 as an alliance of the new stock markets established in Amsterdam (Nieuwe Markt), Brussels (Euro.nm Brussels), Frankfurt (Neuer Markt), and Paris (Nouveau Marché).
} 
market. Like most junior or new markets, it is designed for new, but already structured, companies: their explicit or implicit standards exclude nascent companies.

In most cases, the creation of a junior market is proposed as a complement to start-up financing conventional tools. As stated by the European Venture Capital Association (EVCA, 2004, p.11), "the existence of this type of market allows venture capitalists to quit these SME companies as soon as they are mature enough to be listed on the market. Thus, the financial and human capital of the venture capitalist is freed up and can focus once again on small start-ups". This practitioner argument is grounded in Black and Gilson's (1999, p.36) finding that "VC can flourish especially and perhaps only - if the VC can exit from a successful portfolio company through an IPO, which requires an active stock market". The situation differs in Canada, where the public venture market is a substitute for, or a competitor to, the conventional VC market.

\section{B. Canada}

There are two main stock exchanges in Canada: the TSX (the main market) and the TSXV. In December 31, 2007, there were 1,613 issuers listed on the TSX and 2,338 issuers listed on the TSXV (including NEX listings). As Rousseau (2006) asserts, the market capitalization of about half the listings on the AIM ranges between \$25 million and \$250 million, which places the market in direct competition with the TSX. Heenan Blaikie, one of the leading law firms in the country, considers that the AIM and the TSX offer "a real exit for mature companies not ready for the pros."7 The main Canadian market is devoted to growing companies. Nicholls (2006, p. 160) notes that all but the largest 245 TSX companies are small- or micro-capitalization companies.

Like its predecessors, ${ }^{8}$ the TSXV describes itself as a public venture market with the following distinct features: 1) Provides access to capital for earlier-stage companies or smaller financings; 2) Constitutes a cost-effective stepping stone for international companies looking to list on a quality North American market; 3) Acts as an exchange mandate to mentor the management of newly public companies, and 4) Enables a streamlined graduation to TSX when main market requirements

\footnotetext{
${ }^{7}$ See Eric M Levy, Heenan Blaikie Partner, Alternative Capital markets for U.S. Issuers: TSX and AIM, at http://www.abanet.org/buslaw/committees/CL650000pub/materials/goingpublic.pdf

${ }^{8}$ In 2001 the TSX Group purchased and renamed the predecessor of this exchange, the Canadian Venture Exchange (CDNX), previously created following the merger of the Alberta and Vancouver Exchanges in 1999. In 2001, the Montreal Exchange opted to specialize in derivatives, and transferred its small capitalization securities to the CDNX. We use the term TSXV to refer to this exchange and its predecessors.
} 
are met. ${ }^{9}$ As previously stated, this exchange has very low listing requirements: new companies can list with no revenues; the company's stock price must be higher than CAN\$0.15, and the minimal net tangible assets, including the IPO proceeds, has been set at CAN\$500,000 or $\$ 750,000$, depending on the period. ${ }^{10}$ Using the definitions of small and micro caps given by the Advisory Committee on smaller companies (SEC, 2006), Nicholls (2006) estimates that about 98\% of TSXV companies could be considered micro-capitalization companies. To ease access to the market by developing firms, backdoor listing, ${ }^{11}$ including reverse takeovers (RTOs) and Capital Pool companies (CPCs) are authorized and promoted by exchanges. Capital Pool companies are similar to Special Purpose Acquisition Companies (SPAC) in the U.S. A CPC is a listed corporation (a shell) with no assets (except cash), no business plan and no operating history, and is solely intended to find and acquire assets or companies as takeover targets. Once the qualifying transaction (QT) is completed, the resulting issuer may be listed for regular trading.

VC is indeed present in Canada, with this country generally credited with having one of the highest levels in the world relative to its population or its economy (Baygan, 2003). However, VC-backed IPOs are rare events, and are generally carried out in the TSX market. A few American VCs specialize in natural resources and finance some projects in Canada, but most of the financing in this sector is provided by individuals, sometime through specialized brokers.

\section{Is the TSXV special?}

SME markets generally list firms at a more developed stage than does the TSXV, and cannot be viewed as public venture capital markets. First North could be considered as an exception; it is an alternative marketplace for small growth companies which has already been launched in Denmark (2005), Sweden (2006), Iceland (2007) and Finland (2007). This alternative market is a part of the OMX Nordic Exchange, which is not subject to the requirements that apply to Regulated Markets under EU Securities Markets Law. To be listed on First North, a firm needs neither to show an

\footnotetext{
${ }^{9}$ See Elaine Ellingham: Toronto Stock Exchange and TSX Venture Exchange: Global Leaders in Mining, TSX, March 2005, http://www.nrcan-rncan.gc.ca/mms/invest/2005/rus/pdf/ellingham.pdf

${ }^{10}$ Corresponding values for NASDAQ from June 1999 to June 2001 were US\$4 (price), US\$4 million for shareholders' equity, and US\$5 million for market capitalization.

${ }^{11}$ According to the TSX Manual, a "backdoor listing" occurs when an issuance of securities of a listed issuer results, directly or indirectly, in the acquisition of the listed issuer by an unlisted issuer, with an accompanying change in effective control of the listed issuer. Transactions will normally be regarded as backdoor listings if they could result in the security holders of the listed issuer's owning less than $50 \%$ of the securities or voting power of the resulting issuer.
} 
operating history nor to document profitability or sufficient financial resources, nor to have an established minimal market value. ${ }^{12}$ However, a Certified Adviser (similar to Nomads in the UK) is required at all times. First North provides investors with "the opportunity to invest in a company early in its lifecycle, at a stage of growth and development". In January 2007, the documents posted on First North website mentioned 89 listed companies, with a mean (median) market capitalization of Euro55.8 (Euro19.9) million. These values are equivalent to CAN\$85.53 million and CAN\$30.34 million, respectively. The average gross proceeds of the IPOs on this market come up to Euro19.5 million in $2007,{ }^{13}$ which is equivalent to CAN\$30 million. On average, the firms listed on First North have a capitalization that represents four times that observed on the TSXV, and their gross proceeds are 10 times those reported in Canada for the 2000-2006 period. While First North may seem to be the only SME market with characteristics similar to those of the TSXV, the large proceeds of its IPOs indicate that it cannot be considered as a public venture capital market. Moreover, this market is still too young to lend itself to proper analysis.

The particular strategy followed in Canada can be traced to a set of factors, though no formal causality can be assessed. Firstly, Canada is vibrant in the Mineral and Energy sectors, and has a long tradition of financing activities in the areas, including exploration, through the stock market. Nearly 50 years ago, Walter and Williamson (1960) observed that strong differences "in the kinds of markets maintained on Canadian exchanges for investment-grade industrials and for speculative mines and oils may come as a surprise to one accustomed to the American system of separating these two classes roughly between the exchanges and the over-the-counter market". Secondly, regulators have followed the recommendations of academics (MacIntosh, 1994) and of numerous professionals in easing regulations, mainly through the CPC program, which was originally devoted to resources companies. Thirdly, when technology companies started raising money, VC was not available. The VC industry emerged slowly in the 1970s and, in 1980, there was only CAN\$400 million under management. At the end of 1991 (MacIntosh, 1994), the total amount of VC invested was CAN\$3.3 billion, with this capital mainly oriented toward companies in the later stages of their

\footnotetext{
${ }^{12}$ A presentation of the differences between the main market and First North requirements is available online on the site of the exchange (last visited March 19, 2008), at http://omxnordicexchange.com/firstnorth/company issuers area/Joining_First_North/First_North_o $\mathrm{r}$ the nordic list/

${ }^{13}$ PriceWaterhouseCoopers, IPO Watch Europe, Quarter two 2007 report, online (last visited March 19, 2008) at: http://www.ukmediacentre.pwc.com/imagelibrary/detail.asp?MediaDetailsID=921
} 
development. MacIntosh reports that the average investment was CAN\$1.1 million in 1991. Fourth, policy makers clearly linked the lack of VC to the supply side, and to increase VC offerings, governments implemented poorly designed programs, such as labor-sponsored funds. According to Cumming and MacIntosh (2006), these funds have crowded out private VCs, and globally, have reduced the availability of early stage financing in Canada.

\section{The TSXV and Graduations}

To graduate, TSXV listed companies must comply with the TSX minimal listing requirements. Even though these requirements are higher than those prevailing on the TSXV, they appear to be very low when compared to international standards. In 1998, the TSX introduced the "technology company standards," which required that companies have a minimum of CAN\$12 million in cash, adequate funds to cover all planned research and development (R\&D) expenditures, general and administrative expenses and capital expenditures for a period of at least two years, and a minimum two-year operating history, including R\&D activities. Accordingly, these listing standards allow developing companies to easily access the market while reporting negative earnings, even at a prerevenue stage of their development. ${ }^{14}$ For mineral exploration and development-stage companies, the only quantified requirements are working capital of at least CAN\$2 million and net tangible assets of CAN\$3 million. For industrial companies "forecasting profitability," the TSX requires net tangible assets of CAN\$7.5 million and evidence (satisfactory to the TSX) of earnings from ongoing operations for the current or next fiscal year of at least CAN\$200,000.

As indicated on its website, the TSXV promotes the migration of growing companies, which it strives to help graduate from the TSXV to the TSX "in a more efficient and economical manner than ever before (...) Once a company has gained the skills necessary to operate successfully as a public venture and built a solid financial foundation, it is possible to graduate to a senior exchange such as TSX". The TSXV proposes the following benefits for graduation: ${ }^{15}$ 1) TSX listing application fee will be waived for eligible TSXV issuers; 2) certain issuer information on file with TSXV can be accessed by the TSX; 3) sponsorship requirements may be waived for qualified TSXV issuers; 4) a business development service helps the company in the graduation process. The website proudly highlights successful graduations. The opportunity to graduate is a central

\footnotetext{
${ }^{14}$ See Harris (2006) for an analysis of this change in the listing requirements.

${ }^{15} \mathrm{See}$ http://www.tsx.com/en/listings/venture issuer_resources/graduation_to tsx/index.html.
} 
argument in the promotion of actions organized by the exchange to attract new listings. ${ }^{16}$ The TSXV strategy consists in attracting new listings of companies that cannot list on regular markets, and promoting the migration of the most successful of these firms to the main market. Rash (1994) considers that such a strategy is one of the main reasons accounting for the failure of the first wave of new markets in Europe.

\section{Previous literature AND PROPOSITIONS}

\section{A. Performance and Success Rates}

In the context of the large asymmetry of prevailing information surrounding the financing of new ventures, investors face three forms of risk (Kaplan and Stromberg, 2004): internal or "agency risk" (Fiet, 1995), associated with the unobservable actions of managers, and closely related to agency problems; external risk, induced by uncertainty relative to the market and the competition for the product, is referred to as "market risk" by Fiet; lastly, Kaplan and Stromberg define the "execution risk", which is mainly related to the difficulty in making the technology or the strategy work. Specialized investors, like VCs or business angels, use specific tools and take several actions to limit these various dimensions of risk, both before and after the investment.

VCs and business angels first extract information on the quality of projects (Fiet, 1995; Gompers, 1995) and on the quality of management (Fiet, 1995). This includes information on the people involved, local conditions, and market studies to evaluate the potential of new products. VCs will often screen thousands of deals a year looking for opportunities, and then finance only the most promising. All the functions advanced in the risk control dimension of the investment require time, competencies and resources that are not available to the individual investors involved in the public market. While some of these investors may have the skills needed to analyze deals, the marginal cost of conducting a due diligence process will be substantially higher than the potential gain the investor can realize, given his partial ownership of the firm. The analysis and screening process the specialized investors engage in suggest that, on average, the firms they select will perform better than those that list directly without being subjected to such a screening process. This effect should

\footnotetext{
${ }^{16}$ The TSXV organizes "Accessing Public Venture Capital Workshops" that "go beyond the basics of public venture capital and delivers compelling, first person perspectives on public financing, building your business and sustaining growth. And it provides access to leading public venture capital experts-investment bankers, lawyers, auditors and TSX Venture professionals". The cases of graduating companies are presented as success stories at http://www.numeriqc.ca/Documents/MtlWorkshopInvitation.pdf
} 
be reinforced by the fact that before the financing, venture-backed firms are, on average, more innovative (Engel and Keilbach, 2007) and larger (Puri and Zarutskie, 2007) than non venturebacked firms. Accordingly, our first proposition is: ${ }^{17}$

Proposition 1: The average return of newly listed firms on the TSXV is low.

On the investment date, VCs use incentive contracts and special financing instruments, such as convertible debt or convertible preferred stock, syndication among VCs or limited investment horizons (Tykvová, 2000) to mitigate the agency risk. Moreover, the contracts generally include the possibility for the outside investor to acquire control of the firm. Theories summarized by Kaplan and Stromberg (2004) indicate that pay-for-performance compensation and VC control will increase with this form of risk. Neither incentive contracts nor convertible stocks can be used to control for the agency risk in the public market.

$\mathrm{VC}$ also mitigates agency and external risk after financing by monitoring and advising start-up entrepreneurs (Kanniainen and Keuschnigg, 2004). Cumming et al. (2004) document that VCs have financial, administrative, marketing or strategic/management value-added activities. Finally, VCs contribute to reducing the costs of informational asymmetries (Amit et al., 1998), and can ease subsequent financing rounds. According to Bottazzi et al. (2008), VC investor activism is positively related to the success of portfolio companies. In our context, the monitoring and advising activities of VCs induce a double disadvantage for the firm being developed through the public market, where such activities are unlikely to be systematic. ${ }^{18}$ Firstly, publicly listed firms cannot benefit from the value-added activities, even while they are at a stage of their development when such activities can be crucial, and secondly, the management is not given the opportunity to improve its skills.

\footnotetext{
${ }^{17}$ The lack of detailed data on VC performance in Canada impedes any detailed comparison between the public and the conventional venture capital markets. The only available figure provided by the industry is a mean rate of return for the 1995-2005 period.

${ }^{18}$ Indeed, one or several public investors could be actively involved in monitoring or guiding firms listed on the TSXV, but such involvement is not the rule on a public market. In Canada, most private placements, and even most seasoned equity offerings, are launched by non-profitable public companies. To validate this point, we analyze the 1,157 largest private placements issued by public companies, using the Reports of Trades Submitted on Form 45-501F1 of the Ontario Security Commission, from 2001 to 2005. The proportion for these large placements acquired by institutional investors is around $20 \%$, and in $70 \%$ of all cases, the placements involve more than four investors. In $50 \%$ of the cases we analyze, more than ten investors are involved.
} 
If value-added activities provided by VCs have real value, and if VCs indeed have the screening and monitoring tools they are credited for, then the development of firms that opt for the public market should lag behind that of firms financed by VCs, and these two propositions should be satisfied:

Proposition 2a: The success rate of newly listed companies on the TSXV is significantly lower than the success rate reported by venture capitalists.

Proposition 2b: The time to success is significantly longer for newly listed companies on the TSXV than for companies backed by specialized ventures.

\section{B. Performance of Graduates}

Three stakeholders are involved in the graduation process: exchanges, managers and shareholders. We analyze the motivations of each one to formulate our forecasts relative to the pre-and postgraduation stock price performance.

Exchanges: Traditionally, an exchange listing can be considered a double signal that a firm fulfills existing listing requirements, and will eventually meet ongoing requirements. According to Harris (2006), both signals are especially important in the IPO market. However, in the context of competition for revenues between demutualized entities, particular exchanges may choose one of two strategies. The first consists in maintaining high listing requirements, to preserve a high level of reputational capital, and to keep the cost of capital of listed companies as low as possible. The second strategy involves reducing the listing requirements in order to capture a growing portion of listings and trades. Such a strategy erodes the reputational capital of the exchange. As Harris reports, none of the exchanges has ever proposed to eliminate listing standards, but several of them, including NASDAQ, Amsterdam Exchanges, the Paris Bourse and the London Stock Exchange (LSE), have waived their listing rules during bubbles, mainly as a means of increasing their revenues (Harris, p. 262). Even though the TSX introduced lower standards in 1998 to help R\&D companies, Harris evidences that several companies, even some not meeting minimum listing requirements, have been listed following a discretionary decision by the exchange. Both the TSX and the TSXV can be included in the category of exchanges that are "beginning to view listings as a source of revenue, have pro-actively lowered listing requirements or established new market segments aimed at small, high growth ventures in an attempt to entice firms to float" (Jenkinson and Ljungqvist, 2001, p.29). In this context, the reputational capital of the TSXV and TSX can only be low; the strategy of accepting new listings has limited costs but increases revenues. Listing and trading fees represent the major part of TSX revenues (Harris, Table 1), in contrast with the average 
European exchanges, and so increasing the number of listed companies is therefore more crucial for the TSX than for other exchanges. The TSXV uses the possibility of graduation as a central argument to attract new listings. Increasing the graduation number is in the interest of both exchanges, which are, in fact, two divisions of the same public company. The incentives to accept new listings were particularly acute during the technology bubble, when prices and trading volumes were high. Harris (2006) argues that the stock exchanges currently have strong incentives to act against the public interest in easing the entry of new companies, mainly during hot issues markets.

The incentive of early disposition of successful companies does not exist for VC investors. Rather, they can choose the optimal time, methods and tools to exit (Cumming and MacIntosh, 2003). VCs incur direct costs if they exit too early from a promising investment. The same situation exists for non-VC-backed IPOs. Aside from the urgent need for liquidity, a company has no incentive to enter the market too early. Listing on the main market is thus likely to be more premature among graduating firms than among conventional new listings. If companies graduate before reaching profitability, and without a strong management team, their probability of suffering a liquidity crash will be high (Mudambi and Treichel, 2005).

Management: Two dimensions are relevant here, the first being the reason for, and timing of, the listing change, and the second, the lack of involvement of knowledgeable investors, in the case of graduations.

Managers may decide to exit the venture market and list on the regular exchange for several reasons. The first is growth: managers identify several investment opportunities, and expect to finance these projects at a lower cost of capital on a more liquid market. However, graduates are generally small firms with median shareholders' equity in the vicinity of CAN\$10 million, while several firms on the venture exchange have capitalizations higher than CAN\$100 million. Accordingly, we consider this motivation to be more applicable to the larger graduates than for the smaller ones, which can easily finance their projects from the TSXV. Secondly, managers will contemplate a listing change if they deem that investors prefer high levels of regulation, and will probably value their stocks higher in the more strictly regulated main market. Such a hypothesis is analyzed by Jenkinson and Ramadorai (2007), based on listing changes between the LSE and the AIM. They observe that the initial effects of listing changes on prices are reversed over several months following the change, and suggest that particular investor clienteles exist for the two 
regulatory standards. The differences in regulatory requirements between the TSX and the TSXV are smaller than those prevailing between the LSE (rules-based regulation) and the AIM (principlesbased regulation). Based on the analysis by Jenkinson and Ramadorai, we cannot anticipate significant effects of the listing changes on prices. Lastly, managers may time their listing decisions to take advantage of a temporary good stock valuation. Dharan and Ikenberry (1995) find that after firms move trading in their stocks to the AMEX or NYSE, stock returns are generally poor, probably because managers time their applications for listing - managers of smaller firms, for which initial listing requirements may be more demanding, tend to apply for listings before a decline in performance. Poor post-listing performance is not observed in larger firms. Cheng (2005) finds that the "post-listing drift" is confined to the small set of firms moving from NASDAQ to AMEX during 1981-1990, with small sizes and low book-to-market ratios. He explains that firms are more likely to move their trading locations when the stock prices are higher, but we cannot definitely determine the reasons for listing changes. However, none of the motivations proposed in the literature allow for the anticipation of a strong listing performance, except for larger firms, which graduate in order to finance large investment projects.

The main difference between graduations and IPOs lie in the fact that, for growing companies in the U.S., VCs are often involved in the financing prior to the listing. Compared to IPOs backed by VCs, firms that graduate from the public venture market will suffer a significant disadvantage. As summarized by Chemmanur and Loutskina (2006), several arguments can account for VC-backed IPOs generally performing better (Doukas and Gonenc, 2005) and exhibiting a higher survival rate than conventional IPOs (Jain and Kini, 2000). Firstly, VCs fund only a small minority of firms, and these firms are of better quality than non-VC backed firms; this is the "screening" effect. Secondly, VCs devote a considerable amount of time to monitoring firm management in the pre-IPO stage (Gompers, 1995). The combined effect of screening and monitoring suggests that "the quality of firms brought public with VC backing is likely to be higher than that of non-VC backed firms" (Chemmanur and Loutskina, 2006). A third argument relates to the involvement of the VC in the newly listed firm, after the IPO. As underlined by Lerner (1995) and by Barry et al. (1990), in a significant number of instances, VCs retain a seat on the board of the newly listed firm even after cashing out. As VCs are specialized providers of oversight, Lerner proposes that it might be expected that these firms will be less prone to agency problems. VCs have strong incentives to ensure that optimal governance systems are in place at the time their portfolio firm goes public, as 
their returns depend on the share price at the time lockup rules allow them to sell their stakes; this is the "oversight effect". Empirically, Chou et al. (2006) evidence that expert market intermediaries may help start-ups in their portfolio acquire resources for successful development, which in turn enhances the aftermarket survivorship of IPO-issuing firms. Lastly, Chemmanur and Loutskina evidence a "market power effect". VCs develop long-term relationships with various participants in the IPO market (underwriters, institutional investors, and analysts), and these relationships enable them to attract greater participation by these market players in the IPOs they backed. In turn, the VCs can obtain a higher price for the equity of these firms, as greater support from analysts and institutional investors is generally associated with better performance. To summarize, a firm that lists on the main market after graduating from the public (as opposed to the conventional venture capital) market is likely to suffer from lower quality (screening effect), less skilled management and weaker governance (monitoring effect), less support after the listing (oversight effect) and a lower interest among market participants (market power effect). Ivanov et al. (2008) demonstrate that the reputation of VCs has a strongly positive association with their post-IPO long-run performance. While it provides none of the classical functions usually associated with reputable VCs, the public venture market can be assimilated into low-reputation VCs.

Investors: While investors have no decision making power in the graduation process, they can however, both induce and be influenced by the graduation. If managers time the graduation to coincide with a period when stock prices are abnormally high, then graduations 1) will occur after strong rallies, and 2) are likely to be followed by poor returns. Such a pattern is likely if we note that both the exchanges and the managers have advantages, but face no significant costs in promoting the graduation. That said, it should be pointed out that valuation errors are more likely in some categories of stocks. Stronger underperformance is likely among firms whose value rests primarily on future opportunities, because valuation errors are more likely to be associated with expansion projects than with the refinancing of current activities. Accordingly, graduate firms with no revenues or earnings, as well as those with highly intangible assets, are likely to exhibit a strong pattern of abnormal positive returns before graduation and negative returns on the main market.

This discussion and previous results lead to the following three propositions:

Proposition 3: Graduations from the TSXV to the main exchanges generally follow a significant rally in stock prices. 
Proposition 4: Graduations from the TSXV to the main exchanges are generally followed by abnormal negative returns.

Proposition 5: The long-run performance following graduation should be particularly low for firms exhibiting no revenues and no earnings, and whose projects are highly intangible.

\section{DATA AND STYLIZED FACTS}

\section{A. Data}

This research is based on a massive effort to collect and document new listings on the TSXV and the graduations from this market. Despite its important role in new venture financing, this market has been largely neglected by researchers, probably because of a lack of documented lists and structured databases. The TSXV has undergone several series of transformations and mergers during the last 20 years, and most data relating to it can only be hand-collected from provincial securities commissions. We collected and documented data on new listings from 1986 to 2006, including IPOs, backdoor listings (RTOs and resulting issuers of CPCs), along with the graduations that occurred over the same period. We characterize each new listing at its entrance date and each graduate firm at its graduation time. In addition, we document the post-graduation returns. In total, we identified and documented 3,857 new listings and 827 graduations.

We collected the lists of Canadian IPOs from FPInfomart.ca and from the Financial Post database. Initially, we detected 2,616 IPOs from 1986 to 2006, and retained only the 1,982 issues that were followed by a listing on the TSXV. ${ }^{19}$ We obtain the accounting information from old versions of Thomson's CanCorp Financials database (CanCorp hereafter) and the prospectuses, which are available on SEDAR. The centralized information system (SEDAR, the equivalent of EDGAR in the U.S.) has only been in operation since 1997; data for the previous years were obtained from the Autorité des marchés financiers du Québec, investment bankers, and academic libraries.

Numerous Canadian companies go public by merging with existing but generally inactive companies (RTOs) or with a CPC. Because there is no available list of such operations, we conducted systematic analyses to detect and document these new listings. RTOs have been systematically reported by the TSXV review since 2000. For the previous years, we used a keyword scan, programmed on all the fields of CanCorp to detect each mention of a reverse merger or RTO in financial statements and notes. We then analyzed each transaction and retained only the 825

\footnotetext{
${ }^{19}$ We determine the exchange listing for each issue from the Reviews of the Exchanges, the TSXV website (Infoventure.tsx.com) and SEDAR.
} 
RTOs associated with new listings on the TSXV, from 1988 to 2006 . We collected the main characteristics of the entrant companies from CanCorp and SEDAR.

We went on to compile a list of the CPCs using the new issues published by the Financial $\operatorname{Post}^{20}$ and searches in the Exchange reviews and SEDAR to determine whether the new issues were CPCs. A total of 1,311 CPCs were created during the period, but 1,050 successfully completed the QT required to list a new company. QTs were identified for each CPC using the TSXV website, along with SEDAR, the Survey of Predecessor and Defunct Companies published by the Financial Post (Survey), Lexis-Nexis and Internet browsers. Often, companies use backdoor listing methods to access the market without issuing equity, or they delay the offering for several weeks or months. We analyzed each transaction to determine the amounts collected around the time of listing. We consider that financing is associated with a backdoor listing if it occurs during the 12 months following the listing. We got the gross proceeds by searching in SEDAR and the FPinfomart.ca new issue database.

The TSXV provided us with a list of companies that graduated from January 1, 1995 to April 30, 2007. We supplement these data for the period going from January 1, 1989 to December 31, 1994, using the monthly new listings of the TSX Review. We carefully scanned these lists to collect the new listings originating from migrations from the TSXV (or its predecessors), and obtained an initial sample of 830 graduations. We noted the following situations that did not fit exactly into the mould: Eight graduations occurred simultaneously on the TSX and on a foreign market (NASDAQ). In these cases, we retained the graduation date and any relevant observations. In 16 cases, the TSXV reported a graduation to the TSX, but the company had already listed abroad (NASDAQ, AIM, Frankfurt or AMEX) a few weeks or months prior to being listed on the TSX. We considered such cases as graduations, but the event dates were changed to the date of the first listing on a more senior exchange. Thirdly, four companies had been listed on the OTC in the U.S. before graduating to the TSX. We retained these cases because we found that none of them was an SEC reporting issuer before the graduations. Fourth, we deleted three companies that had initially listed on the Vancouver stock exchange, and had inter-listed on the Montreal stock exchange. Finally, we kept the 60 cases where a graduation occurred simultaneously with a merger, because the TSX reports a graduation when a TSXV listed company is acquired by a TSX listed one. Our sample is

\footnotetext{
${ }^{20}$ Financial Post: Record of New Issues, Cumulative Report, 1986 to 1991, and FPinfomart.ca, from 1996 to 2006. Issues between 1991 and 1995 were supplied by Michael Robinson of the University of Calgary.
} 
thus composed of 827 graduations. To get accounting data for graduate companies, we matched our sample with CanCorp and with the FPinfomart.ca corporate survey. Market data was derived from the DataStream database.

\section{B. Stylized Facts}

Table 1 summarizes the main characteristics of new listings, for each mode of listing, and for the 21 years. Overall, newly listed companies are micro-capitalization corporations, with pre-money shareholders' equity of about CAN\$300,000. They collected limited amounts of money around the issue: the median (mean) gross proceeds are CAN\$650,000 (CAN\$2.08 million), despite the evident need for funds among companies at a pre-revenue or pre-earning stage of development. More than $80 \%$ of all new listings report negative earnings at the listing time, and the proportion of companies accessing the market at a pre-revenue stage is close to $50 \%$. Overall, $48.14 \%$ of newly listed companies are natural resources firms, ${ }^{21}$ and $19.29 \%$ are technology firms.

\section{***Insert Table 1 about here***}

Only slight differences exist between the companies, depending on the listing mode. The median shareholders' equity is CAN\$180,000 for IPOs, and CAN\$320,000 for CPCs, but is larger for RTOs (CAN\$710,000). The proportion of companies reporting no revenues at the listing time ranges from $29.96 \%$ for CPCs to $58.68 \%$ for IPOs; the proportions for companies reporting no earnings at the listing time are $72.33 \%$ and $83.57 \%$, respectively. Median assets of these issuers are CAN\$0.71 million. The proceeds raised by newly listed Canadian companies are significantly lower than the CAN\$4 million to CAN\$5 million average in the Canadian VC market (Baygan, 2003). We estimate the median post-money shareholders' equity at around CAN\$1 million. In terms of size, gross proceeds and stages of development, these new listings have very little in common with the new listings reported in the U.S. penny stock market by Bradley et al. (2006), in the AIM by Derrien and Kecskes (2007) or in the New Markets in Europe (Bottazzi and Da Rin, 2002). They are even smaller than the typical firm financed by VCs.

Our premise is that the TSXV is a substitute to the conventional financing mode for new ventures, and we must then determine the extent to which VCs are involved in new TSXV listings. We obtained a partial list of VC-backed IPOs from Thomson Financial VC Reporter, which we

\footnotetext{
${ }^{21}$ Natural Resources include Energy (Oil \& Gas) and Materials (Mining).
} 
completed and verified by analyzing the list of large shareholders in prospectuses. We identify 42 (138) VC-backed IPOs on the TSXV (TSX) from 1986 to 2006. For the TSXV, VCs are involved in a meager $2.1 \%$ of the total number of IPOs and $1.1 \%$ of all TSXV new listings. Excluding the issuers in the natural resources sectors, where $\mathrm{VC}$ involvement is marginal, the proportion of all VC-backed new listings climbs to $2.1 \%$. In the U.S., the proportion of VC-backed IPOs for the same years is $41.7 \%$ (Ritter, 2006).

\section{PERFormance AND Graduations From the TSXV}

\section{A Global Performance}

Table 2 reports the value-weighted returns of a home-made index of the newly listings on the venture market. ${ }^{22} \mathrm{We}$ consider all the stocks that list on the TSXV or its predecessors, starting from their listing date. ${ }^{23}$ The weights are based on the market capitalization at the beginning of each month. For the sake of comparison, we report statistics on the return distribution of the TSX for the same period. We also report the official index returns for both markets, from 2001 to 2006. Lastly, we report new listing returns for the 1995-2005 period, in order to allow a comparison with the conventional VC market return. We also report the equally-weighted index, but this index is largely influenced by the huge returns of several very small stocks, jumping from 1 to 10 cents. Accordingly, we discuss the value-weighted returns. We set the maximum monthly return to $1000 \%$ (approximately $0.03 \%$ of the distribution), in order to limit the influence of outliers.

Overall, the TSXV outperforms the main market, with the newly listed firm index posting an average rate of return of $15.69 \%$ versus $10.70 \%$ for the main market. However, the standard deviation is $35.40 \%$ for the former market versus $14.34 \%$ for the latter. Similar results appear when the official indexes are used. However, this market is highly volatile, illiquid, and dominated by small and growth stocks: it probably does not compensate adequately for the various forms of risk

\footnotetext{
${ }^{22}$ The current S\&P/TSXV index was created in 2002. Previously, a CDNX index was available, back in 1999. During the previous years, the venture market was composed of several entities, each with its own index. Accordingly, the official indexes cannot be used for a long-term analysis.

${ }^{23}$ To be included in the official S\&P/TSXV index, a firm must represent more than $0.05 \%$ of the market capitalization (approximately CAN\$27 million in 2007), and have been listed at least 12 months. The capitalization criterion excludes approximately $80 \%$ of all listed firms, while the 12-month history requirement excludes all newly listed firms. This can therefore explain the differences we observe between our estimation and the reported S\&P/TSXV.
} 
incurred by investors. The fairness of TSXV returns, after all forms of risks have been considered, is still open to question, and so we have left it for further research.

During the June 1995-June 2005 period, the VC industry reports a meager net annual internal rate of return of $-3 \%,{ }^{24}$ while the new listings index posts an $11.96 \%$ annual rate of return. VC performance is abnormally low in Canada versus the U.S., where an annual return of $27.6 \%$ is reported for the same period, according to the Canadian Venture Capital Association (CVCA). The difference between the returns of the public and private venture markets is economically very large, but we cannot assess its statistical significance.

This is an unexpected result, and our first proposition is not verified. Furthermore, the result is hard to reconcile with the numerous studies that give the private $\mathrm{VC}$ a strong advantage in dealing with new ventures. A first explanation is that the reported VC return is abnormally low, because it includes the very poor return of Labor-Sponsored VC Funds (LSVCC), which benefit from large tax advantages but suffer from poor governance (Cumming and MacIntosh, 2006), and whose invested firms perform badly (Brander et al., 2008). A second explanation could be that the TSXV is largely exposed to the natural resources sector, while the VC is not. To assess the validity of this explanation, we re-estimate the new listings index, excluding the firms belonging to the Mineral and Energy subsectors. Results are reported in Table 2. Excluding the natural resources firms decreases the return of the index, but it still remains significantly higher than the $\mathrm{VC}$ return, and the difference between the public and the private market returns is over 1000 basis points annually. A third explanation for the observed difference could be a competition effect. With quicker and lighter procedures (mainly in the case of RTOs), the TSXV may have captured a significant market share of promising companies usually oriented toward the traditional VC.

***Insert Table 2 about here***

\footnotetext{
${ }^{24}$ See Canadian Venture Capital \& Private Equity Industry Performance data, available online at the website of Réseau Capital, the Quebec Venture Capital and Private Equity Association, last visited March 20, 2008, at: http://www.reseaucapital.com/Statistiques/Stat2005/Performance\%20Study\%20June\%202005.pdf

To our knowledge, performance data are not available for the previous years in Canada. The performance of the US VC industry is reported at http://www.reseaucapital.com/Statistiques/Stat2006/2006_Q4_ForumCanada-France.pdf
} 


\section{B. Success Rates}

The annual number of graduations is shown in the leftmost column of Table 3. From 1989 to December 2006, 802 companies migrated from the TSXV to the main market, for an average graduation rate of 40 companies per year. Over the same period, we observe 516 new listings by IPOs on the TSX, including 122 VC-backed IPOs. Accordingly, the TSXV indeed assumes its role of feeding the more senior market. The growth in listings on the TSX is attributable more to graduations than to IPOs, and we note seven graduations for each VC-backed IPO on the main Canadian market. However, it appears that most of the graduations in the period examined involve companies already listed at the beginning of our period of analysis: between 1986 and 2006, 296 of 802 the graduations are associated with firms that access the TSXV. We report, in the following columns of Table 3, the number of newly listed companies per year and the number of these new listings that graduated before April 30, 2007, by entry mode. For IPOs, the average graduation rate is $6.76 \%$ from 1986 to 2006: only 134 of the 1,982 IPOs during that period graduate. The proportion is $8.64 \%$ for backdoor listings (162 graduations for 1,875 listings). We estimate that 10 of the 42 TSXV VC-backed IPOs graduate, for a success rate of $23.8 \%$. This confirms the results of several previous studies linking VC involvement to a larger probability of success. Overall, the success (graduation) rate of the TSXV is $7.67 \%$.

\section{***Insert Table 3 about here***}

\section{Test of Propositions 2a and $2 b$}

To validate proposition $2 \mathrm{a}$, we need comparable data related to the success rate of VCs. Brander et al. (2008) provide an extensive study of the exit rates, for the whole population of 3,720 Canadian VC-backed firms from 1996 through $2004 .^{25}$ They report a meager exit rate by IPOs of 3.1\% for the population. Moreover, most of the VC-backed IPOs take place on the TSXV, and Brander et al. estimate the rate of IPOs on the main exchange to be $1.8 \%$. This number can be compared to the

\footnotetext{
${ }^{25}$ Amit et al. (1998), for the period going from 1991 to 1996, report that 16\% of firms in which VCs invest exit by IPOs. Cumming and McIntosh (2003) measure very similar proportions of exits by IPOs in the U.S. and in Canada (26.8\% and $26.9 \%$, respectively). However, these papers report the proportions of exit by IPOs relative to all the VC exits, but they do not report the number of IPOs to the population of firms in which the VCs invest. The large difference between these estimations and the proportion reported by Brandel et al. (2008) can probably be traced to the data collection process they implement. They capture 3,720 venture-backed firms whereas the Thomson Financial (Thomson MacDonald) database, which is generally used for VC studies in Canada, identifies only 1,763 invested companies during the same period.
} 
$7.67 \%$ rate which we estimate for the public market. Although the significance of this difference is beyond the testing ability of our data, the public venture market in Canada appears to provide a graduation rate for TSXV listed companies that is approximately four times the exit rate by IPOs on the main market estimated for VCs. While this unexpected result is in line with our first observation of a superior return on the public versus the private $\mathrm{VC}$ market, it does not however confirm our proposition 2a. The average time before IPO exits (success) for VCs is estimated at about 3 years in the U.S. (Cumming and Johan, 2007; Giot and Schwienbacher, 2007), and at about 2.45 years in Canada (Cumming and Johan, 2007). We estimate a mean time to graduation of 5.02 years (standard deviation of 4.29 years), while the median is 3.45 years. The time to graduation is twice as long for TSXV successes as for VC exits by IPO, which is consistent with our proposition $2 \mathrm{~b}$.

In Canada, developing companies through a public venture market takes more time but produces a larger rate of success than does the private $\mathrm{VC}$ market. The VCs finance more firms than the public market (3,720 vs. 1,647 from 1996 to 2004). However, the TSXV feeds the main market more intensively than does the $\mathrm{VC}$ market, at a proportion of seven to one for the whole period we analyzed. One possible explanation for this troubling result may be the influence of Governmentsponsored VC. Brandel et al. indicate that Government-sponsored VC firms have a preference for lower technology industries, such as those in the resource extraction and manufacturing sectors, which are probably less prone to conduct an IPO than the classical technology sectors. Brander et al. assess that enterprises supported by non Government-sponsored VCs are more likely to have successful exits (IPOs or third-party acquisitions), and tend to generate higher value conditional on successful exit. However, there are few indications of a significant effect of the type of $\mathrm{VC}$ on the exit rate by IPO, and the weakness of the private VC market in conducting IPOs on the main market appears to be prevalent in Canada.

\section{Graduation Characteristics}

To be able to study the three-year performance of graduates, we limit the analysis to the 671 cases observed before December 2004, and restrict the sample to the 647 graduations for which accounting data is available. ${ }^{26}$ Table 4 presents the main characteristics of the sample. We first observe that the firms are still micro-capitalization companies, by North American standards. The

\footnotetext{
${ }^{26}$ We obtained a time series of accounting values for the pre-graduation period for only a subsample of the observations. TSXV listed companies are small and generally not followed by conventional databases. This rules out the analysis of the growth rate of graduates, before the event.
} 
median shareholders' equity is CAN\$7.98 million, and the median total assets are CAN\$13.69 million. Seventy-five percent of graduates have shareholders' equity (total assets) lower than CAN\$17.77 million (CAN\$29.18 million). A quarter of the firms report equity lower than CAN\$3.48 million before graduation. Approximately $50 \%$ of the graduates do not meet NASDAQ's minimal listing requirement in shareholders' equity. Half of the firms graduate before attaining profitability, and $26.43 \%$ do not report revenues. This confirms that the TSX, albeit the main Canadian exchange, is devoted to listing emerging companies. Our observations indicate that graduation occurs early on in the development of most companies. At this point, the reasons why several small firms graduate are unclear.

We split our sample into four main sectors: Minerals, Energy, High-Tech (including Biotech) and Other. The first two sectors account for most of the graduations (174 and 212, respectively). This is in line with the heavy weight these sectors command on Canadian stock markets, and with the strong performance of these sectors since 2000. Energy and Minerals companies present very different characteristics before graduation, even though their respective shareholders' equity values are in the same range. Minerals graduates do not report revenues in a very large majority of cases (75.86\%), and $87.36 \%$ have negative earnings. Growth opportunities represent the most prominent part of their valuation, while assets in place represent a very low percentage. The reverse is true for Energy companies, among which only $4.25 \%$ of firms have no revenues, and only $30.19 \%$ report negative earnings. Median total assets are also larger in this sector than in the Minerals sector (CAN\$17.28 million versus CAN\$9.23 million). Differences are noted between High-Tech and Other companies, with the former companies generally having lower total assets, and posting negative earnings in a majority of cases (57.14\%). Among Other companies, 27.46\% report losses. Depending on the sector of activity, the companies thus graduate under very different conditions.

\section{***Insert Table 4 about here ${ }^{* * *}$}

\section{Performances of graduates}

This section presents an analysis of the performance of the population of graduations. These companies migrate from the TSXV to the TSX without being backed by specialized investors, generally credited for favoring good post-listing performance. We examine the three-year pregraduation and three-year post-graduation performance (propositions 3 and 4), using different 
metrics for estimating abnormal (or excess) long-run returns. We then attempt to explain the crosssectional differences in performance that exist following graduation (proposition 5).

Estimating long-run performance is a challenging task, for which several methods have been proposed. The complexity originates from the characteristics of the studied population: like initial issuers, graduate firms generally exhibit lower size and higher growth expectations than the market as a whole, and their performance cannot be compared with that of a conventional index. We constructed and used a benchmark comprised of firms with similar characteristics. Most of the previous empirical works related to new listings, private placements and VC-backed IPOs (Brau et al., 2004) use either one of the event-time approaches, namely, cumulative abnormal returns (CARs) and buy-and-hold abnormal returns (BHARs). ${ }^{27}$ However, these methods suffer from various problems ${ }^{28}$, particularly in the context of our analysis. ${ }^{29}$ Accordingly, we report event-time results only to allow comparisons with previous research findings, and center our analysis on calendar-time methods. As the focus of the paper is not on methodological intricacy, we report some of the details in Appendix 1.

\section{A. Event-Time Abnormal Returns}

Given the particular characteristics of the companies studied, we use size and book-to-market control portfolios as benchmarks for computing abnormal returns. ${ }^{30}$ We report two sets of results, depending on the weighting scheme employed. The equally-weighted (EW) method gives an equal weight to each observation, and the results largely reflect the performance of small capitalized firms, while the value-weighted (VW) scheme for its part lends greater weight to larger firms. Reporting both results allows us to determine whether or not the estimated performance is driven by

\footnotetext{
${ }^{27}$ The biggest advantage of the BHAR estimator is that it precisely measures investor experience.

${ }^{28}$ Event-time approaches indeed suffer from various problems associated with both the measurement of abnormal returns and the specification of tests for non-zero abnormal returns induced by cross-sectional dependence among sample firms (Kothari and Warner, 2007).

${ }^{29}$ Brav and Gompers (1997) analyze these problems in the particular case of VC-backed IPOs. Cheng (2005) provides an in-depth discussion of the weaknesses of event-time methods in the case of listing changes.

${ }^{30}$ To construct these reference portfolios, we extract Canadian firms' book-equity from the Thomson's CanCorp Financials database, and the market equity and monthly stock returns from DataStream. We rank all Canadian stocks each month according to their market capitalizations, and form three tercile portfolios. Independently, all Canadian stocks are also ranked according to their book-to-market ratios, and three portfolios are formed. The returns of the nine monthly rebalanced portfolios are calculated as the valueweighted average of the individual-firm monthly returns in each of the size/book-to-market intersections. Each graduate firm is then assigned a control portfolio based on its market capitalization and book-to-market ratio over the performance test period examined.
} 
just a subgroup of issuers. Table 5 summarizes CARs obtained on the pre- and post-graduation periods with the reference portfolios and with both weighted schemes, and similar results using BHARs.

The CARs over the three-year pre-graduation period are highly significant: $167.53 \%$ (EW) and $75.56 \%(\mathrm{VW})$. This rally is consistent with the hypothesis that graduates are, on average, good performers that post high growth. This observation is also consistent with investors' positive perception of potential graduation. The difference between VW and EW results indicates that small firms rally even more than larger ones. Over the three-year post-graduation period, Canadian graduate firms on average do not post significant underperformance when an EW scheme is used. A significant post-graduation drift of $-14.66 \%$ however appears when a value-weighted scheme is applied. The use of the BHAR method confirms our previous findings of a rally before graduation. The post-graduation performance becomes non-significant, regardless of the weighting scheme used. We confirm the third proposition of a significant rally before graduation, but reject the fourth proposition, which projects significant underperformance following graduation, except for one test (CAR VW).

\section{***Insert Table 5 about here***}

\section{B. Calendar-Time Abnormal Returns}

We estimate abnormal returns through the alphas obtained from the Fama and French (1993) threefactor pricing model (TFPM). In this approach, the intercept ( $\alpha$ in equation 1$)$ from time series regressions is an indicator of the risk-adjusted performance. This parameter has an interpretation analogous to Jensen's alpha in the Capital Asset Pricing Model (CAPM). For example, for the postgraduation 36-month period, we construct our calendar-time portfolio as follows: a graduate company enters our calendar-time portfolio at the graduation date, and is removed 36 months later. We proceed in like manner for the 36-month pre-graduation period. We then calculate the valueweighted return of our graduate firm portfolio, and estimate the following regression:

$$
R_{p, t}-R_{f, t}=\alpha_{p}+\beta_{p}\left(R_{m, t}-R_{f, t}\right)+s_{p} S M B_{t}+h_{p} H M L_{t}+e_{p, t}
$$

The dependent variable of the regression is the monthly excess return of the portfolio $\left(R_{p, t}-R_{f, t}\right)$, which corresponds for a given month, $t$, to the returns of the portfolio of graduate companies $\left(R_{p, t}\right)$ minus the risk-free rate (the monthly rate of 91-day Canadian Government Treasury bills, $R_{f, t}$ ). The 
independent variables are the excess market return and two zero-investment portfolios, which we construct to mimic the risk factors common to all securities. $\beta_{p}, s_{p}, h_{p}$ stand for the loadings of the portfolio on each risk factor: the market, SMB (size) and HML (book-to-market ratio).

Panel A of Table 6 summarizes the pre- and post-graduation performance, using the Fama and French risk factor approach. ${ }^{31}$ The three-year average abnormal performance before graduation is positive and highly significant: $+102.7 \%$. This run-up is in line with the results of previous studies, and with the results obtained via event-time methods. It is also consistent with proposition 3.

Panel B of Table 6 shows that the magnitude of the run-up differs considerably, depending on the graduation subperiod examined: 1989-1994; 1995-May 2000, or June 2000-2004. The outperformance is positive, but not significantly positive in the first period considered (38.4\%). It is very significant during the high-tech bubble (131.6\%), and from June 2000 to 2004 (107.5\%).

In contrast, the long-run performance following graduation is negative, but not significantly different from zero (at the conventional threshold of 5\%) for the whole period examined (-16.6\%), as well as for two of the three graduation periods examined. The abnormal return is significant at the $10 \%$ level during the second period, a result probably attributable to the large number of graduates originating from the technology sector during this period. Using calendar-time portfolios with the Fama and French risk factors, we reject proposition 4: the aftermarket performance of graduate companies is not significantly different from zero.

Loadings reported in Table 6 are important because they allow the characterization of the graduate sample relative to the market. Betas of graduate firms are significantly higher than 1 before and after graduation: graduate companies tend to have less market risk after graduation. SMB loadings are highly significant before and after graduation: graduate companies are still much smaller than their counterparts listed on the TSX. Finally, HML loadings are negative both before and after graduation: graduate firms tend to be more growth-oriented.

\section{***Insert Table 6 about here ${ }^{* * *}$}

The implications of these results are as follows. Firstly, graduate companies perform well before their migration, and provide steady returns to investors. Secondly, their returns following

\footnotetext{
${ }^{31}$ We follow the common practices in reporting only value-weighted results. Equally-weighted results are available from the authors.
} 
graduation are normal, according to standard statistical tests. Economically, the post-graduation return during the 1995-2000 period is highly negative (-32.5\%), but not significant at the 5\% level. This can be traced to the irrationality of pricing that reigned in several sectors during the bubble. Even if they grow without the support of knowledgeable investors, several graduate companies are able to provide reasonable rates of return. We now turn to the explanation of the differences that exist between these performances.

\section{Cross-sectional Variation in Performance}

In Table 7, we report the abnormal returns of graduations by sector. The price run-up of Minerals and Energy firms is similar to that observed for the whole sample: $99.5 \%$ and $100.2 \%$, respectively. It is much greater for technology firms (175.1\%), and much less for the Other sector (60.8\%). This result can be partially explained by the concentration of graduations in the technology sector during the bubble. There are even more significant cross-sectional variations in post-graduation results. Minerals firms posted a significant underperformance during the three-year period following the graduation: $-74.3 \%$. Technology firms followed the same pattern, posting a negative performance of $-53.3 \%$. In contrast, the Energy graduate firms posted a positive but non-significant aftermarket performance (16.6\%), while Other sector firms posted an almost null abnormal performance. The pre- and post-graduation stock price pattern of firms in the High-Tech and Minerals sectors is consistent with the irrational behavior of investors that overreact in anticipation of the graduation. These differences in results can be traced to the differences in the characteristics of the graduates among the sectors. High-Tech and Minerals firms generally graduate without earnings, even before reaching the revenues stage.

Panels $\mathrm{B}$ and $\mathrm{C}$ of Table 7 differentiate results by pre-graduation operating performance. We distinguish companies with revenues from firms with no revenues, and companies with positive earnings from companies with negative earnings. During the three-year pre-graduation period, firms recording revenues realized a significant $134.0 \%$ return, while firms with no revenues generated a non-significant $56.0 \%$ return. During the three-year post-graduation period examined, firms recording revenues posted a non-significant $-10.8 \%$ return, while firms with no revenues exhibited a significant underperformance of $-38.7 \%$. Unexpectedly, firms recording positive and negative earnings achieved similar returns during the pre-graduation period: $89.8 \%$ and $112.6 \%$. However, during the post-graduation period, the former had a positive but non-significant abnormal return 
(12.0\%), while the latter had a significant underperformance of $-53.4 \%$.

These results corroborate the fact that the market in general tends to overreact to the assumed graduation. However, post-graduation underperformance is concentrated in two sectors: High-Tech and Minerals, where this underperformance is driven mainly by firms with poor operating performance before graduation. Our results are consistent with proposition 5, which stipulates that long-run performance following graduation should be particularly low if the real value of the graduate is difficult to assess.

\section{***Insert Table 7 about here $* * *$}

\section{Can the TSXV Model be Improved?}

The public venture capital model used in Canada imposes very limited requirements to new listings. New listings seem to provide investors with a rate of return which is commensurate with that of the main market, and which overrides the rate of return of the conventional VC industry. However, the observed margin between the returns on the main market and on the TSXV portfolio of newly listed firms can hardly compensate investors for the high volatility, the lack of liquidity and the small size of the latter. In this section, we examine the extent to which the graduation, and the period leading up to the event, can be partially predicted by the main characteristics of the issuers at the listing time. We then analyze the potential effect of the application of a simple screening model on the rate of return for investors. The model needs to be simple, because the number of usable variables at the listing date is limited by the nature of the issuers: a sizable proportion of them report no revenues, and all accounting data generally used to forecast failure or success cannot be exploited. Moreover, the length of the period analyzed and the size of the whole sample, composed of 2,472 firms, make it impossible to obtain the data related to ownership and board composition used by Jain et al. (2007) in a similar context.

We consider that the probability to graduate is positively related to the size of the firm at the IPO, and we estimate it using the natural logarithm of the post-listing assets (LOGASSETS). We also argue that a firm reporting earnings before listing should have a better chance to graduate. We introduce a dummy variable equal to one if the issuer has negative earnings per share (DNE), and consider that firms with more growth opportunities are more likely to graduate. We use the classical measure for the relative weight of growth opportunities, the book-to-market (BTM) ratio. We estimate this ratio before the listing, in order to avoid capturing a post-listing valuation effect. It is 
estimated by dividing the shareholders' equity at the end of the previous fiscal year by the simultaneous market value. We introduce dummy variables to consider the effects of the main sectors. We indicate these sectors through the dichotomous variables DMINERAL, DENERGY and DHT, respectively. The operating quality of companies going public in hot markets is assumed to be low (Coakley et al., 2007). We control for this factor by using the geometric return for the 12 months preceding the listing date (RM12M1).

We use Probit models to analyze the probability to graduate and the semi-parametric Cox Proportional Hazards model to identify variables that significantly influence the time to graduation. The models have already been carefully described, in a similar context, by Demers and Joos (2007) and by Jain et al. (2007), and we do not present them in detail in this paper.

Table 8 presents the results of the Probit model. The model is globally significant, meaning that the probability to graduate depends partially on variables observable at the listing time. Only the BTM does not play a significant role, as a result of the difficulty in estimating the book value for growing firms without revenues or tangible assets. Mainly, size is positively related to the probability of a graduation, while the lack of positive earnings and the hot issue period have a negative influence on the probability of success. We report the marginal effects which indicate economic significance. The sector appears to have a stronger impact on the probability to graduate; for example, the inclusion of a newly listed firm in the High-Tech (Mineral) sector increases the probability of graduation by $5.6 \%$ (4.9\%). Though statistically significant, the impact of reporting earnings on the probability to graduate is surprisingly low - reporting negative earnings decreases the probability of graduation by $2.4 \%$. In Table 8 , we also report the results of the Cox model that explain the time to graduation, using the same set of variables as in the Probit model. All variables appear to be significant, except the book-to-market and the dummy variable associated with negative earnings. We report the risk (hazard) ratios to assess the economic significance of our results. For a unit change in the predictor variable, the relative risk ratio of outcome $m$ relative to the referent group is expected to change by this ratio, assuming that the variables in the model are held constant. A 2.302 risk ratio (for variable DHT), for example, indicates that the chance of graduation of an issuer in the High-Tech sector is 2.3 times that of a firm that does not belong to this sector, after controlling for other covariates. These ratios confirm that the differences in the occurrence of graduation are largely associated with the activities of the listed firms. Moreover, the pre-listing market return has 
a negative influence on the time to graduation, while the book-to-market is positively associated. Overall, the model is highly significant.

***Insert Table 8 about here***

To assess whether it is possible to use such a model to invest in more promising firms, we use an out-of-sample forecasting model. We split the whole sample of 2,472 firms entering the TSXV from January 1986 through December 2004 into two subsamples composed randomly, except that we keep the same median size and the same industrial representation in each group. We use the first subsample to estimate the parameters of the Probit model which account for the probability of graduation, as presented in Table 8. We then use the parameter estimates of this model to calculate each firm's probability of graduation in the second subsample. We rank the probabilities obtained and split the second subsample into two groups. For the high- and low-probability of graduation groups respectively, we estimate the monthly average returns, on a value-weighted basis, for the whole period. Accordingly, a stock is included in the portfolio from its inception in the market up to the time of the following event: graduation, delisting or acquisition (when the returns' series ends) or the end of our period of analysis. This strategy mimics that of the conventional evergreen VC. In Table 9, we report the value-weighted portfolio returns.

Using a simple screening model applied to the new listings on the TSXV, we can split the sample into two very different groups. The high probability of graduation group shows an annualized return of $24.45 \%$, versus $6.62 \%$ for the low probability group. Corresponding values for the standard deviation are $78.74 \%$ and $36.27 \%$, respectively. The difference between the average returns in the two groups is not statistically significant, as a result of the high dispersion present. However, the results of this exercise underline two important points. Firstly, using such a rule to screen new listings would allow an investor to largely outperform the (negative) return of the VC industry. Secondly, the stock exchange could probably improve its performance by refining its requirements. The in-depth analysis of the determinants of graduation, success and failure of firms listed on the TSXV is a promising path for future research.

\section{***Insert Table 9 about here***}




\section{CONCLUDING REMARKS}

This paper uses the particular setting that prevails in Canada to analyze how a stock exchange can be used to finance emerging companies and to fulfill the role usually played by formal and informal VC. Several theoretical arguments suggest that such an experience would fail. Emerging businesses present a high level of information asymmetry, and generate agency problems that specialized investors are used to dealing with. They have developed specific tools and the ability to screen the projects (Fiet, 1995), design securities, monitor and counsel management (Kanniainen and Keuschnigg, 2004). These actions and skills allow them to control various forms of risk (Kaplan and Stromberg, 2001), allowing the firms to exit under the best possible conditions, and their market power benefits the firms they list (Chemmanur and Loutskina, 2006). These tools and skills give the VC a comparative advantage over other investors (Gompers, 1995; Amit et al., 1998). The individual investors on the public market own none of these tools, which are considered essential, but they face the same level of risk and asymmetry as VCs. To summarize, the classical wisdom is that VCs have the essential skills, tools and role in screening, monitoring, overseeing and backing new ventures. Without the help of such specialized investors, the growth of new ventures and their success rates are assumed to be low, and a public venture capital market would likely not survive.

The Canadian public venture market is wide open to early stage companies, whose size and gross proceeds are generally lower than those reported for VC investments, and far less than those mentioned in the junior markets in Europe. Canada has developed a specific path used to finance emerging firms, which is different from the classical VC scheme used to provide equity to businesses at the pre-profitability stage. A first and unexpected result is that, on average, the rate of return of this market, estimated using all new listings occurring during the 20 years under analysis, is higher than the rate of return of the main market, and largely higher than the return reported by the VC industry in Canada. An investor seeking exposure to the VC would have made a better choice investing in the public rather than in the conventional market.

According to the definition of the venture exchange itself, successes are defined as graduations of TSXV companies to a more senior market. We measured the success rate of new entrants, and estimated the time to success, from the listing to the graduation date. We then compared these data with data reported for traditional VCs, which usually consider an IPO to be a success. We find that the success rate of the public venture market is approximately four times the corresponding rate for 
traditional VCs. During the period under analysis, the ratio of graduations to VC-backed IPOs was approximately seven to one. The time to success is longer for the public venture market than for the conventional private VC market.

Several arguments indicate that graduation from the TSXV to the TSX could be construed as a "false" success. Notably, both exchanges benefit from promoting early graduation, but investors might be fooled by the prospect of such a promotion, and the positive role assumed to be played by VCs after the listing cannot exist under existing graduation situations. We analyze the long-run performance of the population of newly listed firms that graduate to a more senior market, using concurrent and sophisticated methods, in order to overcome the methodological problems inherent in long-run performance analysis. Graduate firms are still micro caps, by North American standards. Half of these firms graduate before achieving profitability, and almost a quarter of them exhibit no revenues. The graduations generally follow a significant rally in stock prices. The three-year average abnormal performance before graduation is positive and significant. Moreover, the graduations are generally followed by a negative but non-significant underperformance, in contrast with the classical observation of a long-run underperformance following IPOs (Jenkinson and Ljungqvist, 2001). Our observations are not consistent with the proposition that graduations are timed by managers, or are promoted too early by exchanges. Graduate firms provide a strong return before graduation and a fair return thereafter. They can be considered real successes, even though several of them exhibit poor returns after graduation. Arguably, the average post-graduation performance conceals a very large cross-sectional variation in performance. This underperformance is concentrated mainly in the High-Tech and Minerals sectors, and is largely driven by firms that do not report sales before graduation, and whose value lies predominantly in growth opportunities.

The public venture market imposes very minimal restrictions for listing. We attempt to analyze whether simple screening rules, similar to the classical minimal requirements for exchanges, could improve the model. We model the extent to which the graduation and the time to graduation can be explained by the characteristics of firms seeking to be listed. The models are significant, and the out-of-sample test indicates that the application of simple rules strongly influences the rate of return for investors involved in this market. This opens the door to refining the listing criteria in order to improve the performance of this market and the probability of success, which, as underscored by Bottazzi and Da Rin (2005), is extremely crucial. 
The Canadian approach has several advantages, including enabling the listing and financing of numerous new ventures, at a stage where the classical VCs would generally not be involved. The venture exchange feeds the main market with numerous new listings, a performance that the conventional venture market seems to be unable to reach in this country. Lastly, this financing does not require the generous public subsides that conventional VCs have traditionally obtained in Canada. However, the model also has drawbacks. Even though the average rate of return may be commensurate with that of the main market, many investors have realized very poor rates of returns or incurred total losses. This is not inconsistent with high rates of return, given the high level of skewness in the returns' distribution. Among the newly listed firms, a few winners compensate for a large proportion of losers. This market is highly volatile, illiquid, and dominated by small and growth stocks: it probably does not compensate adequately for the various forms of risk incurred by investors. The fairness of TSXV returns, after accounting for all forms of risks, is still open to debate, and we have left it for further research.

A large body of literature insists on the value added by VCs, and on their specific skills and tools available to control for risk and help the growth of new ventures. Our observations indicate that a public market can do better than a classical VC market, in terms of return for investors and feeding the main market. One explanation to this situation can be the disruptive effect that the government has created by granting large tax credits to larger funds, which are credited with poor performance and governance (Cumming and MacIntosh, 2006). According to this specificity of the Canadian market, it is not sure that this experience can be replicated in a country where the VC industry is strong, structured and likely to capture the best projects. In other countries where conditions differ from those in Canada, a public venture market could perhaps be implemented if investors could demonstrate, as in Canada, the capacity to provide several rounds of financing to emerging companies, and assume a preference for risky projects with high return skewness. Probably thanks to a long tradition of financing junior mining and exploration companies, Canadian investors seem to have a strong preference for these types of investments, and sacrifice mean-variance efficiency for higher skewness exposure (Mitton and Vorkink, 2007). Our study provides several elements to answer the two questions included in Bottazzi and Da Rin (2005)'s research agenda. Firstly, there is definitely a place for a stock market targeted at entrepreneurial companies. Secondly, badly structured subsidies to venture financings can have a disruptive effect on the returns of this industry, and contribute to the situation observed in Canada. 
Table 1. Main characteristics of new listings on the TSXV, by listing method and by subperiod, 1986-2006

\begin{tabular}{|c|c|c|c|c|c|c|c|c|c|}
\hline Period & \# & $\begin{array}{c}\text { Mean } \\
\text { GP } \\
\text { in \$M } \\
\end{array}$ & $\begin{array}{c}\text { Median } \\
\text { GP } \\
\text { in } \$ M\end{array}$ & $\begin{array}{l}\text { Asset } \\
\text { in } \\
\$ M \\
\end{array}$ & $\begin{array}{l}\text { SE } \\
\text { In } \\
\$ M \\
\end{array}$ & $\begin{array}{l}\% \\
\text { HT }\end{array}$ & $\begin{array}{c}\% \\
\text { NR }\end{array}$ & $\begin{array}{c}\% \\
\text { REV0 }\end{array}$ & $\begin{array}{c}\% \\
\text { EPSN }\end{array}$ \\
\hline \multicolumn{10}{|l|}{ IPO } \\
\hline 1986-1990 & 1,126 & 1.09 & 0.30 & 0.37 & 0.15 & 11.37 & 54.44 & 65.91 & 85.09 \\
\hline 1991-1995 & 266 & 1.96 & 0.75 & 0.78 & 0.22 & 18.42 & 54.89 & 45.96 & 76.77 \\
\hline $1996-2000$ & 379 & 1.99 & 1.00 & 1.07 & 0.41 & 30.08 & 46.17 & 46.63 & 82.21 \\
\hline $2001-2006$ & 211 & 3.33 & 1.60 & 0.66 & 0.23 & 12.80 & 79.15 & 55.13 & 88.46 \\
\hline $\begin{array}{c}1986-2006 \\
\text { RTO }\end{array}$ & 1,982 & 1.61 & 0.55 & 0.54 & 0.18 & 16.04 & 55.55 & 58.68 & 83.57 \\
\hline $1986-1990$ & 158 & 0.24 & 0.00 & 1.72 & 0.67 & 6.33 & 23.42 & 39.62 & 82.69 \\
\hline 1991-1995 & 229 & 1.31 & 0.28 & 1.57 & 0.97 & 13.54 & 32.31 & 30.19 & 82.86 \\
\hline $1996-2000$ & 199 & 2.38 & 1.00 & 2.05 & 0.84 & 17.09 & 47.24 & 41.01 & 77.21 \\
\hline 2001-2006 & 239 & 6.77 & 2.00 & 1.46 & 0.47 & 19.25 & 57.74 & 46.43 & 74.65 \\
\hline $\begin{array}{c}1986-2006 \\
\text { СРC }\end{array}$ & 825 & 2.94 & 0.66 & 1.60 & 0.71 & 14.67 & 41.58 & 41.00 & 77.84 \\
\hline 1991-1995 & 139 & 2.04 & 1.35 & 1.11 & 0.52 & 15.04 & 59.40 & 23.53 & 64.71 \\
\hline $1996-2000$ & 486 & 2.42 & 1.31 & 0.79 & 0.29 & 27.78 & 37.04 & 27.22 & 69.34 \\
\hline 2001-2006 & 425 & 2.31 & 0.79 & 0.63 & 0.35 & 35.06 & 35.53 & 38.30 & 81.56 \\
\hline 1986-2006 & 1,050 & 2.36 & 1.14 & 0.80 & 0.32 & 29.12 & 39.27 & 29.96 & 72.33 \\
\hline \multicolumn{10}{|c|}{ All types of listings } \\
\hline 1986-1990 & 1,284 & 0.98 & 0.28 & 0.39 & 0.15 & 10.75 & 50.62 & 64.50 & 84.96 \\
\hline 1991-1995 & 634 & 1.67 & 0.60 & 1.09 & 0.41 & 15.92 & 47.61 & 38.76 & 77.45 \\
\hline $1996-2000$ & 1,064 & 2.24 & 1.12 & 1.04 & 0.38 & 26.60 & 42.20 & 37.35 & 75.83 \\
\hline $2001-2006$ & 875 & 3.97 & 1.50 & 0.92 & 0.38 & 25.37 & 52.11 & 45.37 & 79.36 \\
\hline $1986-2006$ & 3,857 & 2.08 & 0.65 & 0.71 & 0.26 & 19.29 & 48.14 & 49.26 & 80.14 \\
\hline
\end{tabular}

The sample consists of 3,857 new listings on the TSXV during the 1986-2006 period. Initial public offerings (IPOs) consist of common shares and other categories of securities (units comprising shares, preferred shares and flow-through shares). Fixed income securities, trust units, limited partnership units and shares resulting from demutualization and privatization are excluded. RTO means Reverse takeovers. CPC means resulting issuers from Capital Pool companies. Gross proceeds (GP), total assets (Asset) and shareholders' equity (SE) are in CAN\$ million (\$M). Variable definitions are as follows: \%HT is the percentage of High-Tech issuers; \%NAT is the percentage of Natural Resources issuers; \%REV0 is the percentage of issuers without revenues, and $\%$ EPSN is the percentage of issuers with negative EPS at the issue. 
Table 2. Comparison of raw returns from Canadian newly listed firms on the TSXV (NL TSXV), newly listed firms which are not Natural Resources issuers (NL NNR TSXV), the main market (TSX) and the conventional venture capital (VC) from the Canadian Venture Capital Association. Portfolios are equally-weighted or value-weighted. IRR stands for internal rate of return. NA means Not available.

\begin{tabular}{lcc}
\hline & $\begin{array}{c}\text { Annual } \\
\text { Return }\end{array}$ & $\begin{array}{c}\text { Standard } \\
\text { Deviation }\end{array}$ \\
\hline 1986-2006 (1,626 NL TSXV) & & \\
Equally-Weighted & $52.16 \%$ & $32.91 \%$ \\
Value-Weighted & $15.69 \%$ & $35.40 \%$ \\
1986-2006 (849 NL NNR TSXV) & & \\
Equally-Weighted & $47.28 \%$ & $30.80 \%$ \\
Value-Weighted & $14.83 \%$ & $42.24 \%$ \\
1986-2006 (TSX S\&P Index) & & \\
Value-Weighted & $10.70 \%$ & $14.34 \%$ \\
& & \\
01/2001 to 12/2006 (TSXV S\&P Index) & & \\
Value-Weighted & $23.57 \%$ & $11.19 \%$ \\
01/2001 to 12/2006 (TSX S\&P Index) & & \\
Value-Weighted & $13.08 \%$ & \\
06/1995 to 06/2005 (1,144 NL TSXV) & & $30.41 \%$ \\
Equally-Weighted & & $34.78 \%$ \\
Value-Weighted & $41.39 \%$ & \\
06/1995 to 06/2005 (632 NL NNR TSXV) & $11.96 \%$ & \\
Equally-Weighted & & $42.52 \%$ \\
Value-Weighted & $35.57 \%$ & \\
06/1995 to 06/2005 (VC) & $7.12 \%$ & \\
IRR & & \\
\hline
\end{tabular}


Table 3. Annual number of new listings (NL) on the TSXV and graduations to the TSX from 1989 to 2006. NA means not available.

\begin{tabular}{|c|c|c|c|c|c|c|c|c|c|}
\hline \multirow[t]{2}{*}{ Year } & \multirow{2}{*}{$\begin{array}{c}\text { Total } \\
\text { Graduation }\end{array}$} & \multicolumn{2}{|r|}{ IPO } & \multicolumn{2}{|c|}{ Backdoor listing } & \multirow{2}{*}{$\frac{\text { Total }}{\text { NL }}$} & \multirow{2}{*}{$\frac{\text { Total }}{\text { Graduation }}$} & \multicolumn{2}{|c|}{ Non-resource } \\
\hline & & Total & Graduation & Total & Graduation & & & NL & Graduation \\
\hline 1986 & NA & 198 & 15 & NA & NA & 198 & 15 & 113 & 7 \\
\hline 1987 & NA & 323 & 16 & NA & NA & 323 & 16 & 153 & 6 \\
\hline 1988 & NA & 349 & 22 & 62 & 1 & 411 & 23 & 176 & 14 \\
\hline 1989 & 33 & 189 & 13 & 64 & 3 & 253 & 16 & 135 & 6 \\
\hline 1990 & 24 & 67 & 3 & 32 & 5 & 99 & 8 & 57 & 7 \\
\hline 1991 & 13 & 39 & 2 & 30 & 1 & 69 & 3 & 36 & 2 \\
\hline 1992 & 28 & 30 & 3 & 52 & 3 & 82 & 6 & 55 & 2 \\
\hline 1993 & 40 & 63 & 6 & 77 & 7 & 140 & 13 & 68 & 9 \\
\hline 1994 & 57 & 69 & 4 & 92 & 9 & 161 & 13 & 77 & 6 \\
\hline 1995 & 47 & 65 & 2 & 117 & 14 & 182 & 16 & 93 & 9 \\
\hline 1996 & 56 & 84 & 8 & 131 & 16 & 215 & 24 & 111 & 15 \\
\hline 1997 & 56 & 137 & 12 & 141 & 13 & 278 & 25 & 136 & 12 \\
\hline 1998 & 47 & 68 & 8 & 161 & 12 & 229 & 20 & 132 & 11 \\
\hline 1999 & 33 & 46 & 4 & 127 & 9 & 173 & 13 & 125 & 9 \\
\hline 2000 & 44 & 44 & 1 & 125 & 6 & 169 & 7 & 111 & 3 \\
\hline 2001 & 27 & 26 & 3 & 109 & 7 & 135 & 10 & 92 & 8 \\
\hline 2002 & 29 & 24 & 2 & 125 & 18 & 149 & 20 & 83 & 8 \\
\hline 2003 & 60 & 29 & 4 & 135 & 16 & 163 & 20 & 74 & 7 \\
\hline 2004 & 75 & 30 & 5 & 105 & 11 & 136 & 16 & 57 & 6 \\
\hline 2005 & 61 & 45 & 1 & 96 & 6 & 141 & 7 & 59 & 2 \\
\hline 2006 & 72 & 57 & 0 & 94 & 5 & 151 & 5 & 54 & 2 \\
\hline $1986-1990$ & 57 & 1,126 & 69 & 158 & 9 & 1,284 & 78 & 634 & 40 \\
\hline 1991-1995 & 185 & 266 & 17 & 368 & 34 & 634 & 51 & 329 & 28 \\
\hline $1996-2000$ & 236 & 379 & 33 & 685 & 56 & 1,064 & 89 & 615 & 50 \\
\hline $2001-2006$ & 324 & 211 & 15 & 369 & 41 & 579 & 56 & 419 & 33 \\
\hline $1986-2006$ & 802 & 1,982 & 134 & 1,875 & 162 & 3,857 & 296 & 1,997 & 151 \\
\hline
\end{tabular}


Table 4. Main characteristics of firms that graduate from the TSXV to the TSX. Financial statements are those preceding the graduation.

\begin{tabular}{|c|c|c|c|c|c|c|c|c|c|}
\hline & \multirow[b]{2}{*}{$\#$} & \multicolumn{4}{|c|}{ Shareholders' equity } & \multicolumn{4}{|c|}{ Total Assets } \\
\hline & & mean & $\begin{array}{c}25 \text { th } \\
\text { percentile }\end{array}$ & median & $\begin{array}{c}\text { 75th } \\
\text { percentile }\end{array}$ & mean & $\begin{array}{c}25 \text { th } \\
\text { percentile }\end{array}$ & median & $\begin{array}{c}75 \text { th } \\
\text { percentile }\end{array}$ \\
\hline \multicolumn{10}{|c|}{ Panel A: by period } \\
\hline $1989-1994$ & 183 & 10.41 & 1.96 & 5.36 & 10.09 & 19.07 & 3.71 & 7.82 & 18.43 \\
\hline 1995-May 2000 & 249 & 17.91 & 4.89 & 8.93 & 18.31 & 36.18 & 8.26 & 14.74 & 34.97 \\
\hline June 2000-2004 & 215 & 16.92 & 4.45 & 10.25 & 22.33 & 30.93 & 6.34 & 18.51 & 35.46 \\
\hline \multicolumn{10}{|l|}{$\begin{array}{l}\text { Panel B: by } \\
\text { industry }\end{array}$} \\
\hline Minerals & 174 & 14.41 & 2.96 & 7.80 & 18.71 & 22.41 & 4.49 & 9.23 & 23.49 \\
\hline Energy & 212 & 15.96 & 4.92 & 9.64 & 18.11 & 27.56 & 9.16 & 17.28 & 31.16 \\
\hline High-Tech & 119 & 10.37 & 3.40 & 6.93 & 13.56 & 18.19 & 5.95 & 10.71 & 19.98 \\
\hline Other & 142 & 20.25 & 2.84 & 6.78 & 22.97 & 51.00 & 6.34 & 16.40 & 53.91 \\
\hline \multirow[t]{3}{*}{ Total } & 647 & 15.46 & 3.48 & 7.98 & 17.77 & 29.60 & 6.00 & 13.69 & 29.18 \\
\hline & & \multicolumn{3}{|c|}{ Revenues } & & \multicolumn{3}{|c|}{ Earnings } & \\
\hline & $\#$ & Mean & Median & $\% 0$ & & Mean & Median & $\%<=0$ & \\
\hline \multicolumn{10}{|c|}{ Panel A: by period } \\
\hline $1989-1994$ & 183 & 22.13 & 1.45 & 31.15 & & -0.08 & 0.00 & 49.73 & \\
\hline 1995-May 2000 & 249 & 15.34 & 4.10 & 20.88 & & -0.14 & 0.06 & 46.59 & \\
\hline June 2000-2004 & 215 & 13.28 & 3.26 & 28.84 & & -0.71 & -0.12 & 53.95 & \\
\hline \multicolumn{10}{|l|}{$\begin{array}{l}\text { Panel B: by } \\
\text { industry }\end{array}$} \\
\hline Minerals & 174 & 4.84 & 0.00 & 75.86 & & -1.14 & -0.53 & 87.36 & \\
\hline Energy & 212 & 7.43 & 3.43 & 4.25 & & 0.15 & 0.24 & 30.19 & \\
\hline High-Tech & 119 & 13.70 & 5.05 & 11.76 & & -1.91 & -0.82 & 57.14 & \\
\hline Other & 142 & 47.03 & 11.30 & 11.27 & & 1.35 & 0.46 & 27.46 & \\
\hline Total & 647 & 16.58 & 2.90 & 26.43 & & -0.31 & 0.00 & 49.92 & \\
\hline
\end{tabular}

Table 5. Abnormal Returns of Canadian companies graduating from the TSXV to the TSX using Cumulative Abnormal Returns and Buy-and-Hold Abnormal Returns

\begin{tabular}{|c|c|c|c|c|c|c|c|}
\hline Panel A: CARs & $\begin{array}{c}\# \text { at the } \\
\text { end }\end{array}$ & EW & VW & Panel B: BHARs & $\begin{array}{c}\# \text { at the } \\
\text { end }\end{array}$ & EW & VW \\
\hline Pre-Listing $(-36 ;-1)$ & 404 & $\begin{array}{l}167.53 \\
(20.81)\end{array}$ & $\begin{array}{c}75.56 \\
(11.38)\end{array}$ & Pre-Listing $(-36 ;-1)$ & 404 & $\begin{array}{c}206.08 \\
(2.73)\end{array}$ & $\begin{array}{l}116.77 \\
(2.46)\end{array}$ \\
\hline Post-Listing $(+1 ;+36)$ & 355 & $\begin{array}{c}3.84 \\
(0.58)\end{array}$ & $\begin{array}{l}-14.66 \\
(-2.82)\end{array}$ & Post-Listing $(+1 ;+36)$ & 355 & $\begin{array}{c}3.72 \\
(0.78)\end{array}$ & $\begin{array}{c}-3.35 \\
(-0.08)\end{array}$ \\
\hline
\end{tabular}

We estimate abnormal returns for the three-year horizon preceding the graduation $(-36 ;-1)$, and the three-year horizon following it $(+1 ;+36)$. The sample comprises graduations that occurred from January 1989 through December 2004 . Cumulative Abnormal Returns (CARs) and Buy-and-Hold Abnormal Returns (BHARs) are estimated relative to size/book-to-market reference portfolios. Portfolios of graduates are equally-weighted (EW) or value-weighted (VW). The $t$-statistics for each parameter are shown in parentheses. 
Table 6. Abnormal Returns of Canadian companies graduating from the TSXV to the TSX using the Fama-French Three-Factor Pricing Model as a Benchmark.

\begin{tabular}{|c|c|c|c|c|c|c|}
\hline \multicolumn{7}{|c|}{ Panel A: Value-weighted results over the whole period (1989 to 2004) } \\
\hline \multirow[b]{2}{*}{ Pre-graduation $(-36 ; 0)$} & Alpha & TSXC & SMB & HML & Adj. $R^{2}$ & Arith $(\%)$ \\
\hline & $\begin{array}{c}0.028 \\
(4.693)\end{array}$ & $\begin{array}{c}1.281 \\
(1.863)\end{array}$ & $\begin{array}{c}0.971 \\
(10.288)\end{array}$ & $\begin{array}{l}-0.212 \\
(-1.374)\end{array}$ & 0.520 & 102.7 \\
\hline Post-graduation $(+1 ;+36)$ & $\begin{array}{l}-0.005 \\
(-1.476)\end{array}$ & $\begin{array}{c}1.158 \\
(2.041)\end{array}$ & $\begin{array}{l}0.475 \\
(9.529)\end{array}$ & $\begin{array}{l}-0.300 \\
(-3.584)\end{array}$ & 0.662 & -16.6 \\
\hline \multicolumn{7}{|c|}{ Panel B: Value-weighted results by subperiod } \\
\hline \multirow{2}{*}{$\begin{array}{l}\text { Period } 1 \text { (1989-94) } \\
\text { Pre-graduation }(-36 ; 0)\end{array}$} & Alpha & TSXC & SMB & HML & Adj. $\mathrm{R}^{2}$ & Arith $(\%)$ \\
\hline & $\begin{array}{c}0.010 \\
(1.660)\end{array}$ & $\begin{array}{c}0.997 \\
(-0.016)\end{array}$ & $\begin{array}{c}0.865 \\
(7.012)\end{array}$ & $\begin{array}{l}-0.118 \\
(-0.586)\end{array}$ & 0.534 & 38.4 \\
\hline Post-graduation $(+1 ;+36)$ & $\begin{array}{c}-0.004 \\
(-0.887)\end{array}$ & $\begin{array}{l}1.005 \\
(0.035)\end{array}$ & $\begin{array}{c}0.511 \\
(5.121)\end{array}$ & $\begin{array}{l}-0.325 \\
(-2.133)\end{array}$ & 0.496 & -15.2 \\
\hline \multicolumn{7}{|l|}{ Period 2 (1995-May 2000) } \\
\hline Pre-graduation $(-36 ; 0)$ & $\begin{array}{c}0.036 \\
(4.092)\end{array}$ & $\begin{array}{c}1.124 \\
(0.589)\end{array}$ & $\begin{array}{c}1.095 \\
(7.148)\end{array}$ & $\begin{array}{l}-0.780 \\
(-2.855)\end{array}$ & 0.517 & 131.6 \\
\hline Post-graduation $(+1 ;+36)$ & $\begin{array}{c}-0.009 \\
(-1.813)\end{array}$ & $\begin{array}{l}1.086 \\
(0.817)\end{array}$ & $\begin{array}{c}0.518 \\
(7.825)\end{array}$ & $\begin{array}{l}-0.264 \\
(-2.237)\end{array}$ & 0.688 & -32.5 \\
\hline \multicolumn{7}{|l|}{ Period 3 (June 2000-2004) } \\
\hline Pre-graduation $(-36 ; 0)$ & $\begin{array}{c}0.029 \\
(2.798)\end{array}$ & $\begin{array}{c}1.437 \\
(1.777)\end{array}$ & $\begin{array}{c}0.837 \\
(5.964)\end{array}$ & $\begin{array}{c}0.009 \\
(0.039)\end{array}$ & 0.448 & 107.5 \\
\hline Post-graduation $(+1 ;+36)$ & $\begin{array}{c}-0.001 \\
(-0.271)\end{array}$ & $\begin{array}{c}1.565 \\
(3.740) \\
\end{array}$ & $\begin{array}{c}0.259 \\
(2.846)\end{array}$ & $\begin{array}{c}-0.221 \\
(-1.538) \\
\end{array}$ & 0.684 & -5.0 \\
\hline
\end{tabular}

We estimate abnormal returns for the three-year horizon preceding the graduation $(-36 ;-1)$, and the three-year horizon following it $(+1 ;+36)$. The whole sample comprises 336 graduations that occurred from January 1989 through December 2004. We examine value-weighted and equally-weighted (monthly-rebalanced) calendar-time portfolio returns. We regress the monthly excess returns to the calendar-time portfolios, $R_{p, t}-R_{f, t}$, on the Fama-French (1993) three-factor model: $R_{p, t}-R_{f, t}=\alpha_{p}+\beta_{p}\left(R_{m, t}-R_{f, t}\right)+s_{p} S M B_{t}+h_{p} H M L_{t}+e_{p, t}$

$\left(R_{p . t}-R_{f . t}\right)$ corresponds for a given month $t$. to the returns of the portfolios of private and public equity issues $\left(R_{p . t}\right)$ less the risk-free rate (the monthly rate of 91-day Canadian Government Treasury bills. $R_{f . t}$ ). $\beta_{p} . s_{p} . h_{p}$ are the loadings of the portfolios on each risk factor: the market (10\% capped index, TSXC), SMB (size) and HML (book-to-market ratio). Alpha indicates the monthly average abnormal return of our graduate firm sample. Arith stands for the arithmetic abnormal return over the period considered. We estimate the weighted least squares (WLS) time series regression in which the weights are proportional to the square root of the number of firms present in each month $\mathrm{t}$. The $t$-statistics for each parameter are shown in parentheses. $\mathrm{H}_{0}$ for the $\beta$ coefficient is $\beta$ equals to one. 
Table 7. Abnormal Returns of Canadian companies graduating from the TSXV to the TSX along sectors, revenues and earnings

\begin{tabular}{|c|c|c|c|c|c|}
\hline & Alpha & Arith $(\%)$ & & Alpha & Arith $(\%)$ \\
\hline \multicolumn{6}{|c|}{ Panel A Industrial distribution } \\
\hline Minerals & & & High-Tech & & \\
\hline Pre-graduation $(-36 ; 0)$ & $\begin{array}{c}0.027 \\
(3.196)\end{array}$ & 99.5 & Pre-graduation $(-36 ; 0)$ & $\begin{array}{c}0.047 \\
(4.859)\end{array}$ & 175.1 \\
\hline Post-graduation $(+1 ;+36)$ & $\begin{array}{c}-0.021 \\
(-3.611)\end{array}$ & -74.3 & Post-graduation $(+1 ;+36)$ & $\begin{array}{l}-0.015 \\
(-2.026)\end{array}$ & -53.3 \\
\hline Energy & & & Others & & \\
\hline Pre-graduation $(-36 ; 0)$ & $\begin{array}{c}0.027 \\
(3.930)\end{array}$ & 100.2 & Pre-graduation $(-36 ; 0)$ & $\begin{array}{c}0.016 \\
(1.433)\end{array}$ & 60.8 \\
\hline Post-graduation $(+1 ;+36)$ & $\begin{array}{c}0.005 \\
(0.786) \\
\end{array}$ & 16.6 & Post-graduation $(+1 ;+36)$ & $\begin{array}{c}0.000 \\
(0.062)\end{array}$ & 0.9 \\
\hline \multicolumn{6}{|c|}{ Panel B Revenues vs. non-revenues } \\
\hline \multicolumn{3}{|c|}{ Firms recording revenues pre-graduation } & \multicolumn{3}{|c|}{ Firms recording no revenues pre-graduation } \\
\hline Pre-graduation $(-36 ; 0)$ & $\begin{array}{c}0.036 \\
(6.396)\end{array}$ & 134.0 & Pre-graduation $(-36 ; 0)$ & $\begin{array}{c}0.015 \\
(1.455)\end{array}$ & 56.0 \\
\hline Post-graduation $(+1 ;+36)$ & $\begin{array}{c}-0.003 \\
(-0.829) \\
\end{array}$ & -10.8 & Post-graduation $(+1 ;+36)$ & $\begin{array}{c}-0.011 \\
(-2.267)\end{array}$ & -38.7 \\
\hline \multicolumn{6}{|c|}{ Panel C Positive vs. negative earnings } \\
\hline Positive earnings & & & Negative earnings & & \\
\hline Pre-graduation $(-36 ; 0)$ & $\begin{array}{c}0.024 \\
(5.249)\end{array}$ & 89.8 & Pre-graduation $(-36 ; 0)$ & $\begin{array}{c}0.030 \\
(3.687)\end{array}$ & 112.6 \\
\hline Post-graduation $(+1 ;+36)$ & $\begin{array}{c}0.003 \\
(0.982) \\
\end{array}$ & 12.0 & Post-graduation $(+1 ;+36)$ & $\begin{array}{c}-0.015 \\
(-3.358) \\
\end{array}$ & -53.4 \\
\hline
\end{tabular}

We estimate abnormal returns for the three-year horizon preceding the graduation $(-36 ;-1)$, and the three-year horizon following it $(+1 ;+36)$. The whole sample comprises 336 graduations that occurred from January 1989 through December 2004. We examine value-weighted (monthly-rebalanced) calendar-time portfolio returns. We regress the monthly excess returns to the calendar-time portfolios, $R_{p, t}-R_{f, t}$, on the Fama-French (1993) three-factor model:

$R_{p, t}-R_{f, t}=\alpha_{p}+\beta_{p}\left(R_{m, t}-R_{f, t}\right)+s_{p} S M B_{t}+h_{p} H M L_{t}+e_{p, t}$

$\left(R_{p . t}-R_{f . t}\right)$ corresponds for a given month $t$. to the returns of the portfolios of private and public equity issues $\left(R_{p . t}\right)$ less the risk-free rate (the monthly rate of 91-day Canadian Government Treasury bills. $R_{f . t}$ ). $\beta_{p} . s_{p} . h_{p}$ are the loadings of the portfolios on each risk factor: the market (10\% capped index), SMB (size) and HML (book-to-market ratio). Alpha indicates the monthly average abnormal return of our graduate firm sample. Arith stands for the arithmetic abnormal return over the period considered. We estimate the weighted least squares (WLS) time series regression in which the weights are proportional to the square root of the number of firms present in each month t. The $t$-statistics for each parameter are shown in parentheses. 
Table 8. Probit model of the probability of graduation from the TSXV to the TSX (Model 1) and coefficient estimates and p-values from multivariate Cox Hazard Models, where the explained variable is time to graduation (Model 2).

\begin{tabular}{|c|c|c|c|c|}
\hline & \multicolumn{2}{|c|}{$\begin{array}{c}\text { Model 1: } \\
\text { Probit Model }\end{array}$} & \multicolumn{2}{|c|}{$\begin{array}{c}\text { Model 2: } \\
\text { Time to Graduation }\end{array}$} \\
\hline & $\begin{array}{l}\text { Parameter } \\
\text { estimates }\end{array}$ & $\begin{array}{l}\text { Marginal } \\
\text { effects }\end{array}$ & $\begin{array}{c}\text { Parameter } \\
\text { estimates }\end{array}$ & $\begin{array}{l}\text { Hazard } \\
\text { ratio }\end{array}$ \\
\hline Intercept & -2.370 & {$[-0.369]$} & & \\
\hline$P$ value & $(0.000)$ & & & \\
\hline DHT & 0.359 & {$[0.056]$} & 0.834 & [2.302] \\
\hline $\mathrm{P}$ value & $(0.001)$ & & $(0.000)$ & \\
\hline DMINERAL & 0.315 & [0.049] & 0.590 & [1.804] \\
\hline P value & $(0.002)$ & & $(0.003)$ & \\
\hline DENERGY & 0.089 & {$[0.014]$} & 0.311 & [1.365] \\
\hline $\mathrm{p}$ value & $(0.439)$ & & $(0.146)$ & \\
\hline LOGASSETS & 0.144 & {$[0.022]$} & 0.288 & [1.334] \\
\hline $\mathrm{p}$ value & $(0.000)$ & & $(0.000)$ & \\
\hline RM12M1 & -0.524 & {$[-0.082]$} & -1.071 & [0.343] \\
\hline $\mathrm{p}$ value & $(0.014)$ & & $(0.009)$ & \\
\hline DNE & -0.155 & {$[-0.024]$} & -0.193 & {$[0.825]$} \\
\hline $\mathrm{p}$ value & $(0.100)$ & & $(0.263)$ & \\
\hline BTM & 0.010 & {$[0.002]$} & 0.034 & [1.035] \\
\hline $\mathrm{p}$ value & $(0.718)$ & & $(0.439)$ & \\
\hline Chi 2 & 65.871 & & 76.772 & \\
\hline Prob $>$ Chi 2 & 0.000 & & $(0.000)$ & \\
\hline
\end{tabular}

The models are estimated using a sample of 2,472 TSXV newly listed firms over the 1986-2004 period. The probit procedure (Model 1) models the probabilities of having DGRADi = 1, with DGRAD being a dummy variable that equals 1 if the firm graduates and 0 otherwise. The marginal effects appear between brackets and indicate the economic significance. The Cox Proportional Hazard procedure (Model 2) models the time to graduation that is measured as the number of months elapsed between the listing month and the month in which the firm graduates. Hazard (risk) ratios appear between brackets (Model 2). DNE is a dummy variable equal to one if the issuer has negative earnings per share (EPS). LOGASSETS is defined by the natural logarithm of the post-listing assets. DHT is a dummy variable set to 1 if the firms produces high-tech products based on the SIC identification and 0 otherwise. DMINERAL is 1 if the industry of the firm is Natural resources and 0 otherwise, and DENERGY is a dummy variable set to 1 if the industry of the firm is Oil and Gas and 0 otherwise. RM12M1 is the geometric return for the 12 months preceding the listing date. BTM is the book-to-market ratio on the listing date. 
Table 9. Out-of-sample value-weighted portfolio returns of Canadian companies listing on the TSXV from 1986 to 2004, along with the probability of graduation.

Average return Standard Deviation $\quad t$ value

High probability of graduation

$\begin{array}{ccc}24.45 \% & 78.74 \% & 0.31 \\ 6.62 \% & 36.27 \% & 0.18\end{array}$

We split the whole sample of 2,472 firms entering the TSXV from January 1986 through December 2004 into two subsamples. We use the first subsample to run the probit model which explains the probability of graduation, presented in Table 8. We then use the parameter estimates of this model to calculate the probability of graduation of each firm in the second subsample. We rank the probabilities obtained and split the second subsample into two groups. For the groups of high and low probability of graduation respectively, we estimate average monthly value-weighted raw returns, including each firm up to the time it delists, graduates, or merges or up to the end of the study period. 


\section{REFERENCES}

Aggarwal, R. and J. J. Angel (1999). "The Rise and Fall of the AMEX Emerging Company Marketplace." Journal of Financial Economics 52(2): 257-289.

Amit, R., J. Brander and C. Zott (1998). "Why do Venture Capital Firms Exist? Theory and Canadian Evidence." Journal of Business Venturing 13(6): 441-466.

Barry, C. B., C. J. Muscarella, J. W. Peavy and M. R. Vetsuypens (1990). "The Role of Venture Capital in the Creation of Public Companies: Evidence from the Going-Public Process." Journal of Financial Economics 27: 447-471.

Baygan, G. (2003). Venture Capital Policies in Canada. OECD Science, Technology and Industry Working Papers, 2003/4, OECD Publishing. 18 p.

Black, B. S. and R. J. Gilson (1999). "Does Venture Capital Require an Active Stock Market?" Journal of Applied Corporate Finance(1999): 36-48.

Bottazzi, L. and M. Da Rin (2002). Europe's 'New' Stock Markets. CEPR Working Paper 3521

Bottazzi, L. and M. Da Rin (2005). Financing Entrepreneurial Firms in Europe: Facts, Issues, and Research Agenda Venture Capital, Entrepreneurship, and Public Policy. Christian Keuschnigg and Vesa Kanniainen (eds.). Cambridge, MA, : MIT Press.: 3-33.

Bottazzi, L., M. Da Rin and T. Hellmann (2008). "Who are the active investors? Evidence from Venture Capital." Journal of Financial Economics Forthcoming.

Bradley, D. J., J. W. Cooney, S. D. Dolvin and B. D. Jordan (2006). "Penny Stock IPOs." Financial Management (Spring): 5-29.

Brander, J. A., E. J. Egan and T. F. Hellmann (2008). Government Sponsored Venture Capital in Canada: Effects on Value Creation, Competition and Innovation. NBER conference on International Differences in Entrepreneurship http://www.nber.org/ confer/2008/IDE/hellmann.pdf

Brau, J. C., R. A. Brown and J. S. Osteryoung (2004). "Do Venture Capitalists add Value to Small Manufacturing Firms? An Empirical Analysis of Venture and Nonventure Capital-backed Initial Public Offerings." Journal of Small Business Management 42(1): 78-92.

Brav, A. and P. A. Gompers (1997). "Myth or Reality? The Long-Run Performance of Initial Public Offerings: Evidence from Venture and Nonventure Capital Backed Companies." The Journal of Finance 52(5): 1791-1821.

Buckland, R. and E. W. Davis (1989). The Unlisted Securities Market. Oxford, Clarendon Press.

Carpentier, C., M. Kooli and J.-M. Suret (2003). Primary Issues in Canada: Status, Flaws and Dysfunctions. Research Paper: Small Business Policy Branch, Industry Canada 65 p.

Carpentier, C. and J.-M. Suret (2006). "Bypassing the Financial Growth Cycle: Evidence from Capital Pool Companies." Journal of Business Venturing 21(1): 45-73.

Cassar, G. (2004). "The Financing of Business Start-ups." Journal of Business Venturing 19(2): 261-283.

Chemmanur, T. J. and E. Loutskina (2006). The Role of Venture Capital Backing in Initial Public Offerings: Certification, Screening, or Market Power? SSRN working paper

Cheng, Y. (2005). "Post-listing Underperformance: Is it Really bad to Move Trading Locations?" Journal of Corporate Finance 12(1): 97-120.

Chou, T.-K., J.-C. Cheng and C.-C. Chien (2006). Does the Involvement of Expert Intermediaries Improve the Survival Profile of IPO Firms? Evidence from Industry Specialist Auditors and Reputable Venture Capitalists. The Joint 14th PBFEA and 2006 FeAT Conference

Coakley, J., L. Hadass and A. Wood (2007). "Post-IPO Operating Performance, Venture Capitalists and Market Timing." Journal of Business Finance \& Accounting 34(9-10): 1423-1446. 
Cumming, D., G. Fleming and J.-A. Suchard (2004). "Venture Capitalist Value-Added Activities, Fundraising and Drawdowns." Journal of Banking and Finance 29(2): 295-331.

Cumming, D. and S. Johan (2007). "Advice and Monitoring in Venture Finance." Financial Markets and Portfolio Management 21(1): 3-43.

Cumming, D. and J. MacIntosh (2003). "A Cross-Country Comparison of Full and Partial Venture Capital Exits." Journal of Banking \& Finance 27(3, Special Issue): 511-48.

Cumming, D. and J. MacIntosh (2006). "Crowding out Private Equity: Canadian Evidence." Journal of Business Venturing 21(5): 569-609.

Demers, E. A. and P. Joos (2007). "IPO Failure Risk." Journal of Accounting Research 45(2): 333371.

Derrien, F. and A. Kecskes (2007). "The Initial Public Offerings of Listed Firms." The Journal of Finance 62(1): 447-479.

Dharan, B. G. and D. L. Ikenberry (1995). "The Long-Run Negative Drift of Post-Listing Stock Returns." The Journal of Finance 50(5): 1547-1574.

Doukas, J. A. and H. Gonenc (2005). "Long-term Performance of New Equity Issuers, Venture Capital and Reputation of Investment Bankers." Economic Notes 34(1): 1-34.

Engel, D. and M. Keilbach (2007). "Firm-level Implications of Early Stage Venture Capital Investment : An Empirical Investigation." Journal of Empirical Finance 14(2): 150-167.

EVCA (2004). European Stock Market Financing for High-Growth Companies. Research Paper, by Ferrary M. et Groslambert B, Business School, Ceram Sophia-Antipolis

Fama, E. F. and K. R. French (1993). "Common Risk Factors in the Returns on Stocks and Bonds." Journal of Financial Economics 33(1): 3-56.

Fiet, J. O. (1995). "Risk Avoidance Strategies in Venture Capital Markets." Journal of Management Studies 32(4): 551-574.

Giot, P. and A. Schwienbacher (2007). "IPOs, Trade Sales and Liquidations: Modelling Venture Capital Exits Using Survival Analysis." Journal of Banking \& Finance 31(3): 679-702.

Giudici, G. and P. Roosenboom (2004). Venture Capital and New Stock Market in Europe. Advances in Financial Economics. G. Giudici and P. Roosenboom: JAI Press. Vol. 10: 1-24.

Goergen, M., A. Khurshed, J. A. McCahery and L. Renneboog (2003). The Rise and Fall of the European New Markets. Venture Capital Contracting and the Valuation of High-technology Firms. J. A. McCahery and L. Renneboog. Oxford: Oxford University Press: 464-492.

Gompers, P. A. (1995). "Optimal Investment, Monitoring, and the Staging of Venture Capital." The Journal of Finance 50(5): 1461-1489.

Harris, A. D. (2006). "The Impact of Hot Issue Markets and Noise Traders on Stock Exchange Listing Standards." University of Toronto Law Review. 56(Summer): 223-280.

Ivanov, V., C. Krishnan, R. Masulis and A. Singh (2008). Does Venture Capital Reputation Affect Subsequent IPO Performance? Available at SSRN: http://ssrn.com/abstract=910982

Jain, B. A., N. Jayaraman and O. Kini (2007). "The Path-to-profitability of Internet IPO firms." Journal of Business Venturing 2(2): 165-194.

Jain, B. A. and O. Kini (2000). "Does the Presence of Venture Capitalists Improve the Survival Profile of IPO Firms?" Journal of Business Finance \& Accounting 27(9/10): 1139-1183.

Jenkinson, T. and A. Ljungqvist (2001). Going Public: The theory and Evidence on How Companies Raise Equity Finance, Second edition. Oxford : Oxford University Press.

Jenkinson, T. and T. Ramadorai (2007). Do Investors Value High Levels of Regulation? Working Paper, Oxford and CEPR 
Kanniainen, V. and C. Keuschnigg (2004). "Start-up Investment with Scarce Venture Capital Support." Journal of Banking and Finance 28(8): 1935-1959.

Kaplan, S. N. and P. Stromberg (2001). "Venture Capitalists as Principals: Contracting, Screening, and Monitoring." The American Economic Review 91(2): 426-430.

Kaplan, S. N. and P. E. R. Stromberg (2004). "Characteristics, Contracts, and Actions: Evidence from Venture Capitalist Analyses." The Journal of Finance 59(5): 2177-2210.

Kooli, M. (2006). Reassessing Canadian IPO Underpricing: Evidence from Common Shares, Capital Pool Companies and Unit Offerings. Initial Public Offerings. G. Gregoriou ed.: Elsevier Finance.

Kooli, M. and J.-M. Suret (2004). "The Aftermaket Performance of Initial Public Offerings in Canada." Journal of Multinational Financial Management 14(1): 47-66.

Kooli, M. and J. M. Suret (2003). "How Cost-Effective are Canadian IPO markets." Canadian Investment Review 16(4): 20-28.

Korcsmaros, K. (2002). "Can Capital Markets Meet The Financing Needs of SMEs." Infrastructure and Financial Markets Review (Inter-American Development Bank.) 8(4): 4-6.

Kothari, S. P. and J. B. Warner (2007). Econometrics of Event Studies. Handbook of Corporate Finance: Empirical Corporate Finance. B. Espen Eckbo (ed.): Elsevier/North-Holland.

Lerner, J. (1995). "Venture Capitalists and the Oversight of Private Firms." The Journal of Finance 50(1): 301-318.

MacIntosh, J. (1994). Legal and Institutional Barriers to Financing Innovative Enterprise in Canada. Toronto, Faculty of Law, University of Toronto.

Mitton, T. and K. Vorkink (2007). "Equilibrium Underdiversification and the Preference for Skewness." Review of Financial Studies 20(4): 1255-1288.

Mizuno, M. (2006). "The Development of Initial Public Offering Markets for Emerging Companies in Japan." Pacific Economic Review 11(4): 489-503.

Mudambi, R. and M. Z. Treichel (2005). "Cash Crisis in Newly Public Internet-based Firms: An Empirical Analysis." Journal of Business Venturing 20(4): 543-571.

Nicholls, C. (2006). The Characteristics of Canada's Capital Markets and the Illustrative Case of Canada's Legislative Regulatory Response to Sarbanes-Oxley. Research Study Commissioned by the Task Force to Modernize Securities Legislation in Canada

Puri, M. and R. Zarutskie (2007). On the Lifecycle Dynamics of Venture-Capital- and NonVenture-Capital-Financed Firms. EFA 2007 Ljubljana Meetings Paper SSRN working paper

Rasch, S. (1994). Special Stock Market Segments for Small Company Shares in Europe - What went wrong? ZEW Center for European Economic Research 94-13

Ritter, J. R. (2006). Some Factoids About the 2005 IPO Market. Working Paper

Rousseau, S. (2006). The Competitiveness of Canadian Stock Exchanges: What Can We Learn from the Experience of the Alternative Investment Market? Research Study Commissioned by the Task Force to Modernize Securities Legislation in Canada

Schulman, M. A. (1999). Small and Medium Size Business Markets. Report, WFSE 60 p. SEC (2006). Final Report of the Advisory Committee on Smaller Public Companies to the U.S. Securities and Exchange Commission. Report, SEC: Washington DC. 241 p.

Tykvová, T. (2000). "What Do Economists Tell Us about Venture Capital Contracts?" Journal of Economic Surveys 21(1): 65-89.

Walter, J. E. and J. P. Williamson (1960). "Organized Securities Exchanges in Canada." Journal of Finance 15(3): 307-324. 


\section{APPENDiX 1}

Event time abnormal returns

CAR: From the first month to the event month q (36), CAR is calculated as:

$\overline{C A R_{1 \text { to } q}}=\sum_{s=1}^{q} \overline{A R_{s}}$ with $\overline{A R_{s}}=\sum_{i=1}^{N_{s}} w_{i, s}^{*} r_{i, s}$

$\overline{A R_{s}}$ : the average abnormal return of the graduate companies portfolio at event time $\mathrm{s}, N_{s}$ : number of firms for which returns are available at event time $\mathrm{s}(\mathrm{s}=1$ to 36$) ; \mathrm{w}_{\mathrm{i}, \mathrm{s}}^{*}$ : weight of firm $\mathrm{i} ; r_{i, s}$ : abnormal return of firm $i$ (the difference between the return from the graduate firm and the control portfolio).

BHAR: The abnormal return from a buy-and-hold strategy $\left(\overline{B H A R}_{1 \text { toq }}\right)$, from the graduation month (1) to the event month q (36), is calculated as:

$$
\overline{\text { BHAR }_{1 \text { to } q}}=\sum_{i=1}^{N_{1}} w_{i, 1}^{*} B H A R_{i, 1 \text { to } q}, \text { where } \mathrm{BHAR}_{\mathrm{i}, 1 \text { to q }}=\prod_{s=1}^{q}\left(1+R_{i, s}\right)-\prod_{s=1}^{q}\left(1+R_{b i, s}\right)
$$

CARs and BHARs are similarly estimated for the $[-36,-1]$ months before the graduation.

\section{Calendar Time abnormal returns}

We have constructed SMB and HML in keeping with Fama and French (1993). Stocks are ranked in July based on their size and book-to-market ratio. The stocks are subsequently sorted into two size groups and three book-to-market groups, corresponding to our universe breakpoints: the stocks above the 50 percent size breakpoint are designated B (for big) and the remaining 50 percent are designated S (for small); the stocks above the 70 percent book-to-market breakpoint are designated $\mathrm{H}$ (for high), the middle 40 percent are designated $\mathrm{M}$ and the firms below the 30 percent book-tomarket breakpoint are designated L (for low). Six value-weighted portfolios, S/L, S/M, S/H, B/L, $\mathrm{B} / \mathrm{M}$ and $\mathrm{B} / \mathrm{H}$ are formed at the intersection of size and book-to-market groups.

$\mathrm{SMB}=((\mathrm{S} / \mathrm{L}-\mathrm{B} / \mathrm{L})+(\mathrm{S} / \mathrm{M}-\mathrm{B} / \mathrm{M})+(\mathrm{S} / \mathrm{H}-\mathrm{B} / \mathrm{H})) / 3$ and $\mathrm{HML}=((\mathrm{S} / \mathrm{H}-\mathrm{S} / \mathrm{L})+(\mathrm{B} / \mathrm{H}-\mathrm{B} / \mathrm{L})) / 2(\mathrm{~A} 3)$

Since the OLS procedure has a weak ability to detect abnormal performance because it averages over months of low and heavy event activity, we use a WLS procedure instead. The weights are proportional to the square root of the number of firms present on each calendar month. Market and all risk factors and portfolio returns are value-weighted and capped. ${ }^{32}$

\footnotetext{
${ }^{32}$ In Canada, the TSX introduced a 10\% capped index in May 1999, in a bid to avoid the risk of concentration in Nortel Inc., which represented up to 35\% of the TSX in September 1999, and a risk contribution of $65 \%$. We use a $10 \%$ cap in all our value-weighted schemes.
} 